\title{
BRØNS MØLLE
}

\author{
Af Anders Malling.
}

Brøns mølle ligger omtrent to $\mathrm{km}$ øst for byen, lidt syd for landevejen fra Brøns til Haderslev. Men den er ikke mølle mere. Dens turbiner, som afløste de gamle møllehjul, er standsede, men Brøns å er ikke derfor blevet arbejdsløs. Dens vand fordeles $i$ lange rækker af fiskedamme, som hører til det forsøgsdambrug, som nu har til huse i mollens gamle bygninger. Efter denne store forandring vil det være naturligt at danne sig et overblik over den gamle vandmolles historie.

Den lokale tradition siger, at den er bygget af Valdemar Sejr. Det er ikke usandsynligt. Han var ikke blot en krigens, men også en fredens mand. vi ved, at han byggede moller, og jordebogen fra 1231 fortæller, at Brøns sogn var kongelev, krongods'. Også 1285, 1286 og 1299 nævnes Brøns som krongods. Det ældste skriftlige vidnesbyrd om møllens eksistens er en ekstrakt fra $\mathbf{1 5 7 9}$ over de årlige visse og uvisse indtægter af hertug Hans den Eldres amter, hans arvedel efter Frederik $I^{2}$. Da skulle møllen svare $2^{1 / 2}$ læster mel, dvs. 55 tønder. Allerede på den tid har den altså været $\mathbf{i}$ god drift. Men når en mølle er så gammel, er det $\mathbf{i}$ betragtning af møllebygningsperioderne sandsynligt, at den er meget ældre, især når den tilhører kronen. De ydre forhold taler også derfor. Brøns var et centrum på egnen. Her stod Danmarks anseligste romanske landsbykirke. Her var Hviding herreds tingsted. Her var et stort og delvis frugtbart opland. Den vandrige å og dalen, som just her indsnævredes, afgav glimrende betingelser for en stor mølle. Vejforholdene var $i$ orden. Når kongens private møller kunne ligge så tæt som Vilslev og Jedsted, og når der fra Brøns var $15 \mathrm{~km}$ til Ribe, ville det næsten være påfaldende, om kronen ikke skulle have en mølle her. Det er da slet ikke usandsynligt, at den gamle tradition har ret, når den nævner Valdemar Sejr som møllens bygmester og forste ejer. Møllerne i Brøns var altså kongelige fæstere, og bønderne var forpligtede til at lade deres brødkorn male hos dem. 
Navne dukker frem af tagen.

Omkring 1600 begynder man gennem uklarhedens tåge at kunne skimte omridsene af møllens historie. Forskellige navne dukker frem og forsvinder igen. Det er ikke let at udrede deres forhold til hinanden, og det er navnlig slet ikke muligt at tegne et billede af det daglige liv på møllen. De kilder, som er bevaret, er retsprotokoller og regnskaber. De første taler kun, når noget ikke er, som det skal være, men tier om det normale og glædelige. Regnskaberne fortæller navnlig om ulykker og hovedreparationer; det er nemlig kongens og ikke møllerens regnskaber, vi har. Det følgende er derfor ikke hele sandheden, men kun brudstykker, og de giver måske på visse punkter et skævt billede.

Om Anders Thomsen, den første, som dukker frem af tågen, hører vi $i$ en retssag fra $1589^{\circ}$. Hans søn Thames Andersen har været indviklet $i$ et slagsmål i Ribe, hvor han i selvforsvar dræbte sin slægtning Jens Hansen fra Kagebøl; han blev pure frikendt, endda uden bøde for drabet. Men 1597 må Anders Thomsen selv betale en daler til kongens kasse for at have givet en mand to slag med en spade, og 1604 må han bøde 10 skilling for at have slået en mand et slag med næven.

Det foregående århundrede synes at have været en opgangstid med stigende priser, men 1599 meldes om flerårig misvækst på grund af tørke. Bønderne avlede intet, og møllerne havde intet at bestille og kom i gæld til kongen. Kristian den Fjerde bemyndigede da lensmanden i Haderslev til at eftergive de uformuende møllere en trediedel, og de ssom noget formuende var" en femtedel af deres gæld. Her hedder det da om Anders Thomsen: „Eftersom Anders Møller udi Brønsmølle haver ogsaa været med efterstaaende af hans aarlige mølleskyld 100 ortug, da efterdi han er noget formuende havde lensmanden efterladt ham 10 ortug mel, altså kun en tiendedel. Anders Thomsen har på den tid været ret velstillet og har tillige ejet en vejrmølle i Spandet, som 0.1620 blev flyttet til Brøns.

1602-3 blev møllehuset i Brøns ombygget; vi har de specificerede regnskaber og kan se, at der har været et grundmuret hus af mursten, og selve møllehuset ud mod åen har været af svært tømmer. Men næste år var det galt igen. Der kom en stor storm og et Guds vejr. Spandet vindmølle blæste om, og i Brøns var der 
stormflod, så vandet underminerede den nye bygning, der dels måtte bygges op igen, dels bringes på ret køl af sseks par skruer udi fire dage ". Det var ikke alene tørke, misvækst, storm og vandflod, som hærgede, men tillige en farlig pest, som bortrev mange mennesker og lagde mange gårde øde. Måske er det alt dette, som gjorde Anders Thomsen træt og fik ham til at træde til side for yngre kræfter.

Tømmermanden Bendit Offersen havde 1600 lavet to mollehjul, og 1602 var han med til at bygge møllehuset. Året efter kaldes han Bendit Møller. Han betaler dog først indfæstningen $i$ regnskabsåret 1605-6. Da han på grund af stormfloden ikke har kunnet male $\mathrm{i}$ et halvt år og dog betalt sin mølleskyld, må han nøjes med at give 30 daler $i$ fæstepenge. Anders Thomsen er imidlertid ikke ude af sagaen; heller ikke er det forbi med ulykkerne. 1606-7 blev mollen igen undermineret af stormflod og måtte repareres. Derpå arbejdede $>$ Bendit Møller og Anders Møller" og flere tømmermænd i 55 dage. De to har måske haft møllen i fællesskab; men nu er det sidste gang, vi hører om Anders Thomsen.

$\mathrm{Nu}$ kom der en rolig periode. Først 0.1620 var det nødvendigt med nye reparationer, men så var freden også snart forbi. Efter Kristian den Fjerdes nederlag i Trediveårskrigen rykkede Wallenstein med sine vilde, hvervede soldater op i Jylland. Også Brøns mølle led under krigen, og Offer Benditsen, som nu er blevet møller efter sin fader, må i gang med store reparationer. Men kongen havde nok heller ikke mange penge, og han var ked af de stadige udgifter til møllerne. Han lod amtmanden i Haderslev optage forhandlinger med mollerne om, at de selv skulle overtage vedligeholdelsesudgifterne. Det ville de ikke gerne, men stillede endelig det modforslag, at de skulle beholde det afleveringspligtige korn til en fast pris, altså betale en fast afgift i penge. Det står ikke helt klart, hvorledes tovtrækningen endte; det ser ud til, at amtmanden har bedt kongen om en fast formuleret mølleordning for Haderslev amt og om myndighed til at afsætte uduelige og genstridige møllere. Midt $\mathrm{i}$ disse forhandlinger kom den store stormflod 1634 og lagde begge møllerne i Brøns i ruiner.

Det var et tungt slag for Offer Benditsen. Han havde i de senere år haft svært ved at betale sin mølleskyld. Fra 1634 til 1636 
havde han slet intet kunnet betale. Kongen nedskrev gælden til det halve, og Offer Benditsen skulle stille borgen for resten. Om han ikke har kunnet dette, vides ikke, men året efter sidder der i hvert fald en ny mand på møllen.

\section{Thomas Pedersen.}

I den store stormflod natten mellem 11. og 12. oktober 1634 druknede der i Brøns sogn 21 personer. I et tingsvidne fra Hviding herreds ting 2 . maj 1636 hedder det, at møllen var »ganske med alle både grundværk og andet bortspøldt og ødelagt, såvel som også vindmøllen derhos i samme storm nederfaldt og siden lagt øde«. Hvordan mølleordningen nu end var blevet, var det dog endnu denne gang kongens sag at bygge ruinerne op igen. Han lod sin overtømrermester Hans Ahnamüller slutte kontrakt med tømmermand Dines Jæger om at istandsætte eller genopbygge følgende vandmøller i Haderslev amt: »Binderup mølle, Brøns mølle, Radding mølle, Alre mølle og Taring mølle" og dertil kom Brøns vindmølle ${ }^{5}$.

Han byggede først vindmøllen i 1635, derefter vandmøllen 1636. Vi har alle de specificerede regninger ${ }^{6}$. Men her dukker nu den nye møller Thomas Pedersen op med to regninger, den ene for udlæg til kalk og sten og kost til murermesteren, den anden for smedearbejde, som det ser ud til, at han selv har udført. Måske har han været smed, før han blev møller. Han har ikke kvitteret på regningen "med egen handt " som de andre, men med sit signet, hvori der står "Thames Pedersen, møller". Han er altså kommet til møllen i forsommeren 1636 og måtte ind under den nye molleordning og betalte sin afgift med en fast sum penge, nemlig 123 rdlr., regnet efter $102^{1 / 2}$ tønder a 1 rdlr. 9 sk. lybsk. Desuden måtte han sørge for den årlige vedligeholdelse. Men han har næppe spundet guld på Brøns mølle. Også han fik krigens svøbe at føle, først Torstenssonkrigen 1643, derefter stormflod 1648, hvorved bøndernes korn blev ødelagt, endelig i vinteren 1656-57 et sammenbrud af en nyligt opført sluse, og da havde Thomas Pedersen ikke råd til at opføre den påny og bad kongen om hjælp ${ }^{7}$. Vi kender ikke svaret, måske er der intet kommet, for kongen fik andet at tænke på med Karl Gustav krigene. Da blev den ene mølle $i$ landet afbrændt efter den anden, og i Brøns blev 
begge mollerne "helt ruineret «. Thomas Pedersen fik dog vandmøllen i gang igen, men døde kort efter, måske 1660 eller 1661.

\section{Peder Thomsen.}

Peder Thomsen er det store navn i Brøns mølles ældre historie. Han havde møllen i fæste i 64 år, fra 1661 til sin død 1725. Men allerede inden han formelt overtog møllen, havde hans unge skuldre været med til at bære byrderne i svenskekrigens tid. Han var født 1640 og var altså kun en ung knøs, da svenskerne i september 1658 brandskattede møllen, det vil sige, at de forlangte en stor sum penge for at lade være med at brænde møllen af. Man havde ikke så mange penge på møllen, og da ser det ud til, at det er den unge søn, der har taget sagen $i$ sin hånd. Så vidt vi kan forstå af kilderne, har han lånt pengene hos andre $i$ sin fars og sit eget navn, og det endda til ingen nytte, for svenskerne ødelagde møllen alligevel. Han overtog møllen i fæste 1661 efter sin faders død, men på grund af »denne tids elendige tilstand « måtte han nøjes med at give 12 rdlr. $i$ indfæstning ${ }^{8}$.

Han begyndte altså med den gæld, han havde stiftet for at løskøbe sit hjem fra fjenden, og dertil kom den gæld han måtte sætte sig i for at få vandmøllen nogenlunde i stand, så han kunne male for de forarmede bønder. Vindmøllen måtte han foreløbig lade ligge i ruiner. Han måtte se at skaffe sig indtægter. Vi ser af et gammelt regnskab, at han har gjort tjeneste som tolder. Hovedvejen gik ikke forbi møllen, men en sandet kreaturvej gav også lidt at bestille. Her er hans toldregnskab fra 1662-63:

Fortegnelse paa huiss som her wed

Brønss mølle er bleffuen fortollet.

Jenss Vollesen vdi Ribe 20 par øxen, er ......... 40 Sk. dansch Noch en friss") med 3 hest, er .............. 3 Sk. dansch Noch en vdaff Wissby med 6 oxen, er ........ 6 Sk. dansch Noch en gammel friss med en hest, er ......... 1 Sk. dansch Noch Essben vdi Randerop med 2 kør, er ........ 2 Sk. dansch Noch haffr Peder Spannet fortollet heste,

foller och følle, 13 støcker, er till hobe ......... 13 Sk. dansch Noch en ballemer ${ }^{* *}$ ) med en koe, er ........... 1 Sk. dansch Noch en Hanss Hanssen vdi Huidding føl och

plag fortollet til hobe, 7 støcker, er .......... 7 Sk. dansch

Summa 36 Sk. L. 1 Sk. d.

*) en friser

**) en mand fra Ballum.
Er 2 Mk. lüb. $4^{1 / 2}$ Sk. 1.

Peder Thomssen egen hand'. 
Han søgte flere gange om at få nedsættelse af mølleskylden, da han ellers ikke kunne få råd til at bygge vindmøllen op igen, men det var $i$ det store og hele forgæves. Da fik han en ny ide. Han sender i 1667 eller måske 1668 en ærbødig skrivelse til amtmanden $^{10}$, hvori han skildrer, at han begyndte med gæld, at han ikke har kunnet få vindmøllen bygget op, og at han undertiden ikke kan male på vandmøllen på grund af vandmangel, om sommeren på grund af tørke, om vinteren på grund af frost, og at møllegæsterne derfor har søgt andre møller, som står under fremmed herskab, hvilket er til ikke ringe skade for $>$ mig fattige karl . Han har nu fået den tanke, at der kunne bygges en lille overfalds vandmølle på den anden side af åen; den kunne gå med en meget mindre vandmængde end den store mølle, og den ville være billigere at bygge end vindmøllen. Til dette formål beder han om at få udvist tømmer fra de nærmeste kongelige skove og de nødvendige sten fra slottet. Med slottet mener han nok Hansborg i Haderslev, som var afbrændt af svenskerne i Torstenssonkrigen; kun de nøgne mure stod tilbage, og stenene fra dem blev spredt vidt om, hvor de kunne anvendes. Denne plan blev godkendt, den lille sparsommelige overfalds vandmølle blev bygget, og vi hører foreløbig ikke mere om vindmøllen.

I 1670 må han til at tænke på at ombygge slusen; den kunne $i$ reglen ikke stå mere end 13 år. I de følgende år har han så store udgifter på forbedring og fornyelse, at >den fattige karl « får sin mølleskyld eftergivet 1673 . Men vi kan af regningerne på disse store arbejder se, at mølleren tumler med store planer, og at han er ved at få hovedet over vandet. I de næste 12 år hører vi slet ikke noget om møllen; det er gode tegn; Peder Thomsen er ved at komme på den grønne gren, og i disse år bliver han da også gift med Magdalene Ambders af en af de førende borgerslægter $i$ Tønder.

Iøvrigt var disse år for hele landet en genopbygningens tid, men det var dyrt for kongen at få alle sine moller bygget op igen. Rentekammeret bestemte da, at mølleafgifterne skulle sættes noget ned, og til gengæld skulle fæsterne overtage alle vedligeholdelsesudgifter. Møllerne blev ligefrem udbudt til licitation efter disse nye regler. I en lang skrivelse byder Peder Thomsen 75 rdlr. år- 
ligt for sin egen mølle, og efter at den var blevet synet, endte det med, at han fik den for 80 rdlr. i $1687^{11}$.

Det er en mærkelig historie. Både Peder Thomsen og hans fader havde haft vedligeholdelsespligten, og nu får han altså nedsættelse i sin afgift for at overtage en pligt, som han havde i forvejen. Hvorledes skal det forstås? Man kan måske antage, at administrationen havde glemt, at molleren $\mathrm{i}$ forvejen havde vedligeholdelsespligten, men man kan også antage, at når der nu skulle holdes licitation over hele Haderslev amt, følte man sig bundet aff, at ingen bød højere end de 80 rdlr.

Men sagen bliver mærkeligere endnu. Skønt Peder Thomsen med egen hånd underskriver den nye kontrakt om de 80 rdlr., bliver han faktisk ved at betale 123 i de følgende år, indtil afdøde amtsskriver Peter Hansens regnskaber bliver revideret i 1702. Revisoren henstiller da, at Peder Thomsen skal have en tilbagebetaling på 43 rdlr. for 15 år, ialt 645 rdlr. Det gik dog ikke igennem, men for eftertiden betaler Peder Thomsen kun 80 rdl. om året. Her skjuler der sig måske noget, som vi ikke længere er i stand til at opklare.

Der går nu atter en halv snes år, hvor der ikke meldes noget om møllen, og derved kommer man til året 1698 , som står på de søjler, der bærer pulpituret i Brøns kirke. Da må Peder Thomsen altså have meddelt kirkestyrelsen, at han ville skænke kirken et orgel, og man har begyndt at bygge et pulpitur for at kunne modtage denne gave. "Den fattige karl er blevet en rig mand, og han har ikke glemt, at velsignelsen kommer ovenfra. Og gaven er virkelig stor, et orgel på 11 stemmer, svarende til det store kirkerum, og med en prægtig barokfacade, der er smykket med udskårne akantusblade. Man må endda løfte loftet lidt over orglet, for at den skønne facade kan få plads. En mundtlig tradition vil vide, at orglet først har stået 75 år $i$ en kirke i Hamborg, og når loftet $\mathrm{i}$ kirken måtte løftes, kunne det også tyde på, at orglet ikke oprindeligt var bygget til denne plads.

Menighedens og vel især præstens Peder Ægidii Dalers taknemlighed kommer til orde i en senere opsat mindetavle med en svulmende latinsk indskrift: 
Vend, læser, øjnene hid,

se på dette seværdige og rosværdige

kirkeorgel,

som til Guds ære og kirkens pryd

er opstillet her ved siden med betydelige omkostninger

ved den $i$ sandhed kristne mands,

Peder Thomsen Møllers

velgørenhed og gavmildhed,

med samtykke af hans meget fromme hustru

Magdalene Ambders.

Hidkaldt til at udføre arbejdet

Herman Schaffehardts.

Det blev begyndt år $1698 \mathrm{i}$ december måned,

fuldendt år $1699 \mathrm{i}$ juni måned.

Et ønske at tilføje:

Det behage Gud rigeligt at gengælde

denne gavmildhed med gavmildhed

og at pryde, skænke og velsigne

begge disse ægtefæller,

som har prydet dette Guds hus,

her på jordens bo med jordisk lykke,

hist i Himlens bo med himmelsk ære.

Slutningen af indskriften kunne tyde på, at mindetavlen er opsat allerede inden Peder Thomsens død.

I årene efter 1700 synes Peder Thomsen stadig at have haft økonomisk fremgang. Det var en opgangstid. Vel rasede den store nordiske krig, som også berørte Sønderjylland, men i det store og hele var man ved at komme på ret køl igen. Og i hvert fald forstod Peder Thomsen at navigere og skaffe sig indtægter. 1710 forpagtede han tienderetten i Skærbæk sogn, og for årene 171520 forpagtede han for 20 rdlr. strandretten til vrag og gods i den del af Hviding og Kalvslund herreder, som hørte under Haderslev. De ekstraordinære skatter, som blev opkrævet i anledning af krigen, fortæller os også, at Peder Thomsen ikke var nogen jæun bonde mere. Han gik med paryk, og hans kone gik med højt opsat hår (fontange). Det måtte man svare skat af, 3 rdlr. for hver. Der krævedes også skat af tjenestefolkene, en femtedel årsløn, og deraf ved vi, at Peder Thomsen hjemme havde en møllersvend, en karl og en pige, som fik henholdsvis 10,7 og 4 rdlr. om året. Formueskat svarede han af 1000 rdlr., og af sin mølleforpagtning 10 rdlr. $^{8}$ 
Da Peder Thomsen var 85 år gammel, mærkede han, at det lakkede mod enden, men der var endnu noget, han skulle have ordnet. Han måtte sørge for, at det kære orgel i Brøns kirke kunne blive vedligeholdt gennem tiderne, og han mátte gøre sit til, at man altid i Brøns havde en degn, som kunne spille på det. Desuden var der jo de fattige at betænke. Han stiftede da et legat, som årligt skulle yde 4 rdlr. til orglets vedligeholdelse, 4 rdlr. til organistens underhold og 13 rdlr. og 1 mark lybsk til sognets fattige. Fundatsen er i sin helhed gengivet som bilag 1.

Han havde skønnet ganske rigtigt. Han skulle ikke leve længe efter dette. Han døde 12. aug. 1725 og blev begravet i Brøns kirke. Nu er hans ligsten indmuret i våbenhusets nordvæg. Det er en smuk og anselig sten, hvis hovedindskrift står $i$ et cirkelrundt midterfelt, der er omsluttet af en krans af akantusblade. Over og under midterfeltet er der ovale felter med skriftsteder og i hjørnerne ornamenter. I det øverste felt står der: "Se, ieg vil oplade eders Graffuer og hente eder, mit Folck, af dem. Ezek. 37 «. Skriftstedet i det nederste felt er afslidt. I midterfeltet ser man øverst Kristus med sejrsfanen; på hver side af ham står der en vinstok, hvis tunge klaser bøjer stokken ind imod ham, et såre skønt symbol for et ægtepar, der har modtaget rigeligt af Guds velsignelse og derved nødes til taknemlighed og velgerninger. Herunder stảr så selve indskriften:

»Her huiler erlig oc velacht Mand Peder Thomsen, fordom Moller i Brons Molle, som salig udi Herren hensofuet Anno 1725 den 12. Aug. udi hans Alders 85 Aar. Med sin kiere Hustru erlig oc gudfrycktige Matrone Magdalene Peders, som salig udi Herren hensof Anno 1733, den 20. Jan. udi hendes Alders 78 Aar. Gud gifue dennem en glædelig oc ærefuld Opstandelse paa den yderste Dag^.

\section{Husfoged A. Simonsen.}

Efter Peder Thomsens død kom der en periode på 100 år, hvor fæsterne på Brøns mølle kom fra Løgumkloster og undertiden stadig hørte mere hjemme der end i Brøns. Den første af disse Løgumklosterfolk var krigskommissær og husfoged A. Simonsen, om hvem vi ikke ved ret meget. Han overtog mollen 4. sept. $1725^{12}$. Om nogen auktion hører man ikke noget ved den lejlighed, men da han ligesom Peder Thomsen gav 80 specier i fæste, tør man måske formode, at han har benyttet sin stilling indenfor admini- 
strationen til at skaffe sig dette gode aktiv på de hidtil gældende billige betingelser. Men glæden varede kun kort. Allerede 1733 afgik Simonsen ved døden.

\section{Birkefoged Andreas Andersen.}

Efter Simonsens død blev der holdt licitation over Brøns mølle, og birkefoged Andreas Andersen fra Løgumkloster blev den højstbydende med 450 rigsdaler courant.

Andreas Andersen stammede egentlig fra Svanstrup i Brede sogn, men $i$ et par år havde han været ansat som medhjælper $i$ birkedommerembedet i Løgumkloster for sin morbroder Chr. Hansen under dennes sygdom. Deraf beholdt han siden titlen. Chr. Hansen, som var ejer af Faargaard, var gift med en datter af godsforvalter Nic. Clausen på Trøjborg, en søster til biskop Hans Adolph Brorsons moder. Han sad i birkedommerembedet et halvt hundrede år og blev efterfulgt af Detlev Outzen, Andreas Andersens svigersøn, som vi senere skal høre mere om.

Man skulle synes, at Andreas Andersens bud på Brons mølle var ganske antageligt; det var mere end det femdobbelte af, hvad de tidligere forpagtere havde givet. Amtmanden mente dog, at prisen burde være højere, og der blev holdt en ny licitation, hvor der slet ikke kom noget bud. Der blev da bestemt en tredie licitation, hvor Andreas Andersen gentog sit bud på 450 rdlr. årlig for en tolvårig forpagtning. Myndighederne var stadig utilfredse, og rentekammeret gav amtmanden besked om at få Andersen til at nøjes med en seksårig forpagtning, og det endte med, at man blev enig om 8 år.

I 1735 blev der oprettet et særligt slesvig-holstensk kammer, som fra 1738 fik myndighed til at foretage indstillinger direkte til kongen, selv om rentekammeret på en måde stadig var den overordnede instans. Det blev ophævet igen 1746. Det var altså dette kammer, som 1740 meddelte kongen fra Gottorp, hvor det havde sæde, at birkefoged Andersens kontrakt udløb til den følgende majdag. Der havde været afholdt en ny licitation, hvor Andersen var blevet højstbydende for de følgende 6 år med 320 rdlr. årlig. Da dette var 130 rdlr. mindre end hidtil, havde man undersøgt møllens forhold og fundet, at Simonsen kun havde givet 80 rdlr. på egen reparationsbekostning, og tidligere da kon- 
gen skulle vedligeholde møllen, havde den kun givet 123 rdlr. Kamret foreslog derfor, at man tog mod Andersens tilbud, og det approberede kongen den 15 . nov. $1740^{14}$. Der blev oprettet en kontrakt, som er bevaret, og som vel indeholder omtrent det samme som den tidligere, der er gået tabt. Den går i hovedsagen ud på følgende:

1. Birkefoged Andersen har fuld ret til mollen med to under. falds- og et overfaldshjul, mølledammen, dæmningerne på begge sider, to agertofter, den nordre og den søndre, og en lille eng øst for mølledammen, kaldet Møllerholm.

2. Han skal holde bygninger, sluser og den lange bro $i$ god stand og aflevere det således. Han skal være ansvarlig for uforsigtighed med lys og ild og tage vare på frislusen i stærkt regnvejr. Kun uafvendelige ulykker er undtaget.

3. Med hensyn til tvangsgæster og hoveriarbejde skal det være som hidtil.

4. Ved uafvendelige ulykker, som omfatter hele landet, hvilke Gud i nåde afvende, såsom krig, pest og lignende, kan forpagteren håbe på moderation, hvis skaden overstiger halvdelen af hans normale indtægt af møllen.

5. Forpagteren skal betale 320 rdlr. cour. med halvdelen til mortensdag og halvdelen til majdag, og som sikkerhed sætter han både sin nuværende og sin fremtidige ejendom $i$ pant ${ }^{15}$.

Birkefogeden havde altså møllen noget billigere $\mathrm{i}$ de næste 6 ár, men har nok ikke spundet guld alligevel. I den foregående periode havde kornpriserne været ret lave og landbruget stillestående. I den kommende periode hindrede det fromme onske, der blev udtalt $i$ kontraktens $\$ 4$, ikke en voldsom kvægpest $i$ at udbryde 1745. Det nyttede ikke noget overfor denne sygdom, at man slukkede ilden $\mathrm{i}$ alle gårde og med besvær optændte en ny ild ved at bore $i$ træ, til det blev varmt, og derefter drive kvæget gennem denne nye ild. Det nyttede heller ikke noget, at bønderne den 15. dec. besluttede, at singen må understå sig at føre hornfæ til byen inden kyndelmisse næstkommende, såfremt de vil undgå ovrighedens straf «, om end man må indrømme, at denne forholdsregel var mere fornuftig end den foregående. På Schackenborg gods bortrev sygdommen 2765 stk. hornkvæg, på 'Trøjborg 2711, i Lustrup birk 480, i Riberhus birk 1282, siger amtmand 
Gabel i Ribe. De to største åndens mænd, som dengang fandtes j landet, sukkede hver på sin vis derover. Holberg skrev på sit prosa: "Det synes at ligesom ved Guds besluttede råd er beskikket os, at alt vort hornkvæg skal forgå ". Og Brorson omtalte flere gange sagen $i$ landemodeprotokollen som Guds nidkærheds ild « eller $\gg$ Guds ris, den fordærvelige fæsygdom, som endnu bliver ved iblandt os til bevis på, at han ikke har nået det, han søger ${ }^{16}$. Hvad var det, Gud sagte? Naturligvis, at mennesker skulle omvende sig. Han havde advaret ved at sende en stor komet 1744 , men da folk ikke lod sig advare, måtte kvægpesten jo komme. Brorson skrev endog en salme om denne kvægpest, hvori det hedder:

$$
\begin{aligned}
& \text { Gamle, Unge, Arme, Rige, } \\
& \text { Kommer, folger, vender om! } \\
& \text { Ja, hvo denne gang vil svige } \\
& \text { Bærer Herrens Vredes Dom. } \\
& \text { Børnene paa Moders Knæ, } \\
& \text { Ja det arme, dumme Fæ, } \\
& \text { Alle, hver en Blode-Draabe } \\
& \text { Op til Gud i Himlen raabe }
\end{aligned}
$$

Man kunne måske sige, at kvagpest ikke vedkommer mølleren, men dels havde han dog også kvæg, dels var hans kår afhængige af bondens.

Han havde desuden andre vanskeligheder. Særligt måtte han kæmpe for at gennemføre molletvangen, som var ret almindelig i Slesvig. Det vil sige, at bønderne $i$ et bestemt distrikt havde pligt til at lade deres brødkorn male på en bestemt molle, og samtidig havde visse "tvangsgæster « en hoveripligt til at udføre visse arbejder for deres mølle. Denne tvang skyldtes naturligvis en finansiel betragtning. Når møllen var sikker på et bestemt antal faste kunder, var mølleren også i stand til at betale en større forpagtningsafgift af den. For Brøns mølles vedkommende går denne tvang langt tilbage. Peder Thomsen beklager 1668, at møllegæsterne søger andre moller, fordi der er vandmangel hos ham, men han pukker ikke på tvangen. Men $i$ hans kontrakt af 1687 står der ellers tydeligt nok i § 3 :

-Det forsikres næunte moller $\mathrm{i}$ hans kgl. majestæts navn, at under-såtterne, som fra gammel tid indtil nu med rette har været henlagt til Brøns mølle og stadig er det, uforandret skal være henlagt til den sam- 
me mølle og dermed ogsá uvægerligt skal forrette den sædvanlige tjeneste med korsel af jord (til dæmningerne) og bygningstommer og det nødvendige hândarbejde som hidtil, nảr de af molleren făr besked om det i tide ${ }^{18}$.

I Andreas Andersens kontrakt af 1741 er ordlyden noget mere befalende, men tvangens omfang lidt mere udflydende, hvilket nok betyder en skærpelse af hoveripligterne. Der tilføjes da også den trusel, at de kongelige embedsmand ved passende midler skal holde bønderne til at gøre deres pligt. Men mens det af Peder Thomsens kontrakt fremgår, at molleren selv kunne give ordre angående hoveriet, blev det senere sảdan, at mølleren skulle opgive til husfogeden, hvilket arbejde, der skulle udføres, hvorefter denne gennem sognefogederne skulle give bønderne ordre.

Forst fra Andreas Andersens tid hører man om vanskeligheder ved at gennemføre mølletvangen. Bønderne havde håndkværne hjemme, hvorpå de ogsá malede sadant korn, som møllen havde monopol pâ. Pâ de adelige godser, hvis jord lå spredt mellem de kongelige gårde, blev der bygget møller, som i mange tilfælde lå meget nærmere for de kongelige møllers tvangsgæster, og som søgte at konkurrere ved at male for nedsat pris. Fra Andreas Andersens tid har man en fortegnelse over mollens tvangsgæster ${ }^{10}$. Den indeholder navne pä de kongelige bønder i hele Hviding herred, som dengang var større end nu, nemlig Højrup sogn 55, Arrild 46, Skærbæk 88, Brøns 61, Rejsby 38, Hviding 41, Vester Vedsted 14, Farup 3, Seem 4, Spandet 8, Roager 24, Vodder 36, ja der er endda et navn fra Møgeltonder og et fra Roost, ialt 420. Fra Farup skulle man altså køre forbi møllerne i Ribe og $15 \mathrm{~km}$ videre til Brøns, og hvor mange møller man passerede fra Møgellonder til Brøns, skal være usagt, men man forstår tvangsgæesternes fristelse. Disse vanskeligheder vedblev lige til mølletvangen i Slesvig blev ophævet 1. jan. 1853, men de var særlig store på Andersens tid.

Da forpagtningsperioden atter var ved at lobe ud, blev der igen holdt licitation den 2 . febr. 1747, men denne gang kunne man byde dels på åremål, dels på arvefæste. Andersen bød da $450^{1 / 4} \mathrm{rdlr}$. årlig for 6 år, men kun 422 rdlr. årlig for arvefæeste. Det kan administrationen ikke forstå; arvefæste må da være det mest værdifulde, og rentekammeret forlanger en nærmere udtalelse. Ander- 
sen indsender da d. 6. marts en udførlig erklaring ${ }^{20}$, hvori han hævder, at forpagtningsafgiften er drevet alt for højt op. Møllegæsterne maler deres malt pâ hândmøller hjemme, og andre lignende overtrædelser går hyppigt i svang. Mølleren kan ikke komme dem til livs uden kostbare processer, som han ikke har råd til at føre på grund af den høje pagtsum. Hvad nu særligt arvefæste angår, forholder det sig jo sådan, at møllebygningerne og mølleværket skal betales ved overtagelsen efter stedfunden taksation. Når renterne af denne kapital bliver lagt til den sum, han har budt for arvefæste, kommer man rigeligt op på den sum, han har budt for en forpagtning på åremål.

Da Vorherre imidlertid har velsignet ham med mange små børn, og da han er nodt til at tænke på deres og hans stakkels kones nødtørftige underhold, er han nødt til at bekvemme sig til alt, og så vil han da også i Guds navn tage mollen i arvefæste for den samme sum, som han har budt for en forpagtning på åremål, nemlig $450^{1 / 4}$ rdlr., men på følgende betingelser:

1. At der ikke i Hviding herred bliver bygget nogen anden mølle, hverken på Logumklosters jord eller andetsteds.

2. At alle mollegæster skal være forpligtet til at bringe den malt og rug, som de skal bruge $i$ deres husholdning, til mollen og lade det male der.

3. At han må betale forpagtningssummen een gang årlig, nemlig 1. maj.

4. At alle møllepligtige, som ikke $i$ et fjerdingar eller et halvt àr har besøgt møllen, skal betragtes som overtrædere og være forpligtet til at rense sig på tinge, uden at mølleren behøver at føre proces imod dem, og i hvert fald skal de godtgøre ham skade og omkostninger.

5. At der må blive ham udvist to egetræer og et bøgetræ for en billig betaling til at bestride den meget tunge årlige vedligeholdelsespligt.

Da nu kongen ved Andersens antagelse af tilbudet om arvefæste faktisk får 30 rdlr. mere ind for møllen, háber han til gengæld, at kongen vil gå ind på disse fem punkter, da de jo ikke er til skade for kronen, men tværtimod sigter til at opretholde møllerettighederne.

Rentekammeret fejer hastigt Andersens betingelser til side med 
undtagelse af den "anden «, nemlig at han mả betale til maj i stedet for to gange om året. Da det jo ikke er den anden, men den tredie betingelse, kunne det tyde på, at man ikke har læst Andersens erklæring med megen tålmodighed. Det ender med, at han bøjer sig, og rentekammeret indstiller til kongen, at han skal have forpagtningen for $450^{1 / 4}$ rdlr. cour., så meget mere som det slesvigske kammer 1740 erklærede, at han ikke kunne give mere end 320 rdlr., når han skulle eksistere, og desuden overtager han nu ved arvefæste alle byrder. Det skinner tydeligt igennem, at rentekammeret mener at have gjort en god forretning, og mâske skjuler der sig også et lille hip til det nyligt nedlagte slesvig-holstenske kammer. Kongen bifalder da også indstillingen og bemærker, at der skal indsendes en kontrakt til godkendelse ${ }^{21}$.

Denne kontrakt, som i mere end 100 år blev Brøns mølles grundlov, indeholder $\mathrm{i}$ det store og hele de samme bestemmelser som kontrakten fra 1740. Andersen skal årligt betale 450 rdlr. 12 sk. cour. i arvefasteafgift. Een gang for alle skal han betale 725 rdlr. 14 sk., som møllen er takseret til. Når den går videre til hans arvinger i nedadstigende linje, skal der betales en rosenobel (en fin engelsk guldmønt) i fæstepenge. Han og hans arvinger skal holde mollen med alt tilbehør i god stand og holde den brandforsikret. Indtræffer der ulykker, skal han udbedre skaden på egen bekostning. Ved uafvendelige lands-ulykker kan han vente moderation, hvis hans indtægter af møllen derved falder til mindre end halvdelen af det normale. Han må ikke tage mere $i$ told end sædvanligt; det var i Slesvig en tyvendedel af det malede korn ${ }^{22}$.

Man kunne nu tænke sig, at Brøns mølle med dette arvefæste var kommet ind under gode og rolige forhold. Men det betød $i$ virkeligheden, at møllerens afgifter var sat betydeligt op. Landbruget havde trykkede kår, selv om en opgangstid var ved at begynde. Skovene var forsvundet i svenskekrigene, så det kneb med at få materialer til vedligeholdelse, og priserne steg. En møllesten, som før kunne fås for 20 rdlr., kostede nu 50-60 rdlr. Og bønderne anskaffede hândkværne i stigende tal. Det er ikke alene birkefoged Andersen, der klager derover, men således lyder det fra hele landet. Og endelig indtraf der $1740-60$ en række jordskælv, som mærkeligt nok fik til følge, at vandmængden i de danske åer formindskedes betydeligt, så det fik en skæbnesvan- 
ger virkning for mange møller. ${ }^{23}$. Vi ved ganske vist ikke meget om dette for Brøns mølles vedkommende, men $i$ hvert fald havde Andersen svært ved at klare sig. 1755 var han kommet $i$ restance for to år og havde kun formået at stille kaution for det ene år. Rentekammeret havde rykket ham og havde fảet en lang skrivelse fra ham, hvori han søgte om en halvårlig udsættelse og henviste til de store udgifter, han havde haft til byggeri og reparationer på mølleværket, og navnlig besværede han sig over, at mere end en trediedel af møllegæsterne kun kom sjældent eller aldrig, men lod male andre steder. Som svar bad rentekammeret amtmanden om at se på møllebygningerne og værket og udtale sig om, hvorvidt man kunne give Andersen udsættelse uden at risikere nogen skade for de allerhøjeste kongelige interesser ${ }^{20}$.

Amtmanden svarede den 19 . nov. 1755 , at det var rigtigt nok med byggeomkostningerne. Både beboelseshuset, møllehuset og sluserne var i forfald, da Andersen overtog dem (formentlig 1747) men nu har Andersen bygget et helt nyt beboelseshus op fra grunden, og møllehuset og sluserne er kommet i god stand. Derfor har han ikke kunnet betale sả prompte.

Det var også sandt, at mange møllegæster søgte andre møller, dels fordi de var nærmere, dels fordi de kunne nøjes med det halve toldkorn. Mange af møllegæsterne har langt til mølle, skriver han. Fra Hviding sogn har de bedre vej til Ribe, og fra Vester Vedsted sogn har de til Ribe bymølle en halv fjerdingvej, men til Brøns mølle halvanden mil. I Roager sogn har man til Skallebæk mølle under grevskabet Schackenborg en fjerdingvej, men til Brøns en mil. I Højrup sogn til Gjelsbro mølle under godset $\mathrm{Ny}$ bøl en fjerdingvej og til deres pligtmølle i Brøns fem fjerdingvej. De møllepligtige undersåtter i Spandet og Seem er helt nær ved Skallebæk mølle, og til Brøns har de fem fjerdingvej. I Arrild sogn er der til møllerne i Løgumkloster og til Branderup mølle en halv mil og til Brøns mølle over 1 mil. Disse vejlængder må nu stå for amtmandens regning, de stemmer ikke alle lige godt, men han har i hvert fald ikke overdrevet. Han drager den slutning, at det er let forståeligt, at de fjerne sogne sjældent eller aldrig besøgte deres pligtmølle i Brøns, og det var til stort tab for Andersen. Men de havde i hvert fald denne pligt, som de ikke 
kunne slippe for uden at træffe aftale med molleren og yde ham en godtgørelse.

$\mathrm{Nu}$ har Andersen imidlertid fået den ide, at hver møllegæst skal have en bog, hvori det bliver indført, hvor meget han har ladet male. Så kan man føre kontrol med, at tvangsgæsterne lader male så meget, som der bruges i en almindelig husholdning. Hvis de ikke gør dette, kan man skride ind, og så må vedkommende søge at rense sig eller bøde for sin forseelse. Denne tanke synes amtmanden at billige, da det ellers vil være umuligt for mølleren at tjene så meget, at han kan betale den fastsatte pagtsum.

Endelig henviser amtmanden til et taksationsdokument, som han vedlægger. Ifølge dette dokument, der gengives $i$ sin helhed som bilag, er mollen nu vurderet til 2508 rdlr. 32 sk. Man kan derfor godt give Andersen henstand eller lade ham betale halvårlig, thi hvis betalingen ikke falder, som den skal, er der fuld sikkerhed for restancen ${ }^{20}$.

Det er meget interessant at studere dette taksationsdokument nøjere. Sammenligner man det med et inventarium*, som blev optaget i 1725, lægger man mærke til en del forskelle. Den lange bro har fået den dobbelte bredde. I det store mollehus er nu alle 7 fag optaget af mølleriet, så man har måttet bygge en tilbygning med en lille lejlighed til mallersvenden. Men her har vi tillige for første gang en beskrivelse af møllerens private bygninger, beboelseshuset og udbygningerne, og det viser sig at være en ganske herskabelig bolig, en meget rummelig beboelseslejlighed og en mængde udhuse af forskellig art. Man forstår så godt, at Andersen hellere ville bygge sig et sådant hus end betale sin molleafgift. De fleste af udbygningerne stammer antagelig fra Peder Thomsens tid, men hvorledes hans salshus har set ud, ved vi ikke, da Andersen har bygget sit hus op fra grunden. Han har også bygget smedien og af hensyn til brandfaren tækket den med tegl, mens alle de øvrige bygninger var tækket med strå.

Hvorledes det nu er gået med birkefoged Andersens gode ide med s kontrabøger * over møllegæsternes besøg, ved vi ikke, men med restancerne gik det sådan, at hans svigersøn lagde pengene ud og mere til. Det var birkefoged Detlev Outzen, som havde overtaget Faargaard og birkedommerembedet ved Christen Hansens død 1753. Om nu Andersen har været træt af vanskelighe- 
derne, eller om svigersønnen med gældsbrevene $\mathrm{i}$ hånden har lagt pres på ham, lader sig ikke afgøre, men vist er det, at Andersen $i$ april 1756 søger at sælge møllen til Outzen. Sagen får dog et overraskende og uhyre dramatisk forløb.

Købekontrakten er opsat 7 . april. Outzen skal overtage alle Andersens rettigheder og pligter ifølge arvefæstekontrakten. Men salget skal naturligvis have kongelig konfirmation, og Andersen ansøger rentekammeret derom. Det meddeler rentekammeret til amtmanden og beder ham om en erklæring i sagen, idet det dog forstår sig af sig selv, at møllen ikke kan sælges til svigersønnen, men kun til hans hustru. Arvefæstekontrakten lyder jo på, at møllen overlades til Andersen og hans efterkommere i nedstigende linje, altså nok til en datter, men ikke til en svigersøn.

Amtmanden forstår vinket og ved, hvad han skal erklære, men papir skal der til. Han lader sagen gå videre til sin juridiske medarbejder, som efter lange redegorelser svarer, at møllen kan gå over til datteren, men ikke til svigersønnen, hvorpå amtmanden svarer rentekammeret, at møllen efter hans mening kan gå over til datteren, men ikke til svigersønnen. Selv om Detlev Outzen på Faargaard vil gå ind $\mathbf{i}$ alle Andersens rettigheder og pligter og sætte hele sin ejendom $i$ pant på, at forpligtelserne skal blive overholdt, er det dog klart, at der er tale om et regulært salg til Detlev Outzen og hans arvinger, hvilket strider mod arvefæstekontrakten. Derimod kan Andersens datter, som er gift med Outzen, få møllen for sig og sine arvinger, idet Andersens øvrige arvinger udelukkes. Meget papir og blæk er anvendt på at gore dette klart, og det komiske ved sagen er, at alle instanser er klare over, at det kun er ord, og at realiteten er den, at Outzen får møllen, når hans kone får den. Da rentekammeret således har fået den onskede erklæring, indstiller det salget til kongens konfirmation i den form, at det er datteren, som er køber, og det konfirmerer kongen.

Men hverken Andersen eller Outzen opfatter den skete ændring i købekontrakten som en formalitet. Hvad der nu sker, er ikke helt klart. Måske er Andersen blevet overrasket eller har fortrudt salget. Måske er Outzen blevet fornærmet og har ikke på disse betingelser villet betale sin svigerfaders gæld. Vist er det imidlertid, at Andersen indsender en besværing til rentekammeret over, 
at salget ikke er gået $i$ orden, som han ønskede det, og derfor forlanger han, at den kongelige konfirmation af salget skal omstades, og at han selv skal indsæettes i sine forrige rettigheder som kongelig arvefæster på Brøns mølle. Derover kommer rentekamret naturligvis $i$ stor konfusion og sporger amtmanden om hans mening. Han tygger på sagen en måned og indsender så en lang redegørelse, som røber, at han heller ikke kan begribe, hvad der er gået for sig. Men næsten $i$ forbigående fortæller han, at Outz.en er blevet så rasende, at han sammen med herredsfoged Clausen i Haderslev har beskyldt sin svigerfader for et eller andet kriminelt og har fået ham kastet i fængsel, men at Andersen dog ved andre instansers mellemkomst er blevet losladt igen. Outzen har åbenbart også indgivet en klage i sagen, hvori han har hævdet, at han har betalt sin svigerfaders restancer på 900 rdlr., og at denne desuden skylder ham 2400 rdlr., som han har papirer på, og 300 rdlr., som han ikke har papirer $\mathrm{pa}^{20}$.

Hvorledes denne uhyggelige familiestrid er endt, får man desværre ikke at vide. Amtmanden synes at mene, at Andersen skal have mallen igen, og det har han vel også fået. Men da kilderne ganske svigter for de næste 14 års vedkommende, ved vi faktisk intet om sagens videre forløb eller om stemningen mellem svigerfader og svigersøn. Heller ikke ved vi noget om, hvad datteren, den stakkels Christine Hanne, har følt ved at blive malet mellem disse to hårde møllesten. Først 1770 viser et nyt dokument, at Detlev Outzen nu er blevet ejer af Brøns mølle. Efter hans død er Christine Hanne ejer af møllen. I virkeligheden har hun også ejet den, mens hendes mand levede. Men han optræder $i$ hvert fald $i$ sil eget navn. selv om han kun har været hendes kurator.

\section{Kancellirdd Outzen og frue.}

Detlev Outzen var søn af ridefoged Hans Outzen i Roost, hvis bedstefaders epitafium hænger i Brøns kirke. I modsætning til sin svigerfader var han virkelig birkefoged i Løgumkloster birk. Han havde overtaget embedet 1753 efter Chr. Hansen, og samtidig havde han overtaget Faargaard, hvor han stadig havde sin bopæl. På møllen i Brøns havde han en bestyrer. På Faargaard byggede han stuehuset, som det står endnu. Her forte han et stort hus. Folketællingen fra 1769 meddeler, at der på Fårgård opholdt sig 
birkefoged Outzen og hans hustru med 7 børn, desuden en søster til hustruen, endvidere en teologisk kandidat, der virkede som børnenes informator, og dertil 5 karle, 2 piger og 2 hyrdedrenge. I Sogn kirke byggede han til Faargaards folk et pulpitur, hvorom han længe stredes med kirkeværgerne, da han havde bygget det mod deres ønske. Striden blev dog bilagt, da han gik ind på at betale 6 mark af pulpituret årligt. Faargaard ejede ogsá en begravelse i kirken; formentlig hviler Outzen selv deri; men nu er hans store ligsten opstillet $i$ kirkens våbenhus. 1780 blev han udnævnt til kancelliråd, 1783 døde han, hvorefter hans enke overtog Brøns molle og holdt en forpagter der. Måske har hun også nogen tid selv opholdt sig på mollen; hun holdt i hvert fald fast på sin stol i Brøns kirke. Hun synes ikke at have været særlig bevandret i skrivekunsten, hun skrev "med påholden pen ‘, men hun kan jo også have fået gigt. Hendes svigersøn pastor Friedrich Gabriel Braun, der først var præst i Nørre Løgum og siden i Brede, optræder som hendes kurator efter hendes mands død. Den datter, som var gift med pastor Braun, hed Cathrine Steenbæk Outzen, et navn, der understreger forbindelsen med den Brorsonske familie. Hun døde i Brøns præstegård 1832, 75 år gammel.

I Outzens tid skete der en væsentlig forandring ved Brons malle; der blev påny bygget en vejrmølle. Muligvis er Peder Thomsens lille overfalds-vandmalle gået $i$ forfald; vi horer $i$ hvert fald ikke mere om den. Men den 27. april 1772 fik birkefoged Outzen kongelig bevilling til at lade opfore en "Gryn-, Gruber- og KornVejrmalle*. Han skulle selv betale omkostningerne og selv skaffe en byggeplads til den; til gengæld skulle den være hans privatejendom. Men den skulle være uadskilleligt forbundet med vandmøllen. Hvis der kom en ny arvefæster på denne, skulle han købe vejrmøllen af arvingerne efter den tidligere arvefæster efter en rimelig taksation. Men der skulle ikke være tvangsgæster ved vejrmøllen. Der skulle betales en årlig afgift af den på 12 rdlr. Hver gang mallen tilfaldt en ny arvefæster, skulle der søges bevilling for den påny.

Outzen holdt en bestyrer på mollerne i Brons, men han fulgte selv med i enkelthederne ved deres drift. Anderledes blev det efter hans død. Christine Hanne har næppe magtet at føre et 
sådant tilsyn og så derfor sin fordel ved at forpagte møllerne ud til den højstbydende. Det blev i 1786 Jes Lassen fra Ballum, som skulle betale $1130 \mathrm{rdl}$. årlig og desuden overtage vedligeholdelsen. Forpagtningen gjaldt en tolvårig periode. Kontrakten, som er bevaret $^{24}$, nævner ud over de tidligere indretninger og bestemmelser også halvparten af fiskeriet og ålefangsten, sthi den halve Part af Fiskerierne reserverer sig Fruen selv «. Man mærker husmoderen. Der nævnes også den frie udskænk $i$ huset. Forpagtningssummen skulle betales sudi god gangbar Myndt, dog Halv-Parten i Sølv klingende Myndt". Brandpengene betaler fruen selv, og skulle møllen brænde ved lynnedslag, skal hun bygge den op for assurancesummen og eftergive forpagteren 100 rdlr. for afbræk $i$ hans næring under opbygningen. Han skulle endvidere rette sig efter en kontrakt, der var indgået med møllegæsterne fra Højrup sogn, som mod en betaling af $7 \mathrm{td}$. og 7 skp. rug havde frihed til at lade deres korn male, hvor de ville. Han skulle shvert Aar engang lade Vand-Hiulene, Axlerne og Fyrre-Bielkerne, samt TræVærket paa Veyer-Mallen overstryge med Tiære og Bruunrød: men ved Molle-Huuset giøres sligt kuns hvert andet Aar*.

I kontrakten findes en paragraf, der nærmere omtaler mølletvangen og hoveriet. Den lyder $i$ sin helhed:

De undersåtter, som til dato beviislig have hørt til Vand-Møllen, skulle efterdags som Molle-Giæster forblive dertil: hvilke ere følgende:

\begin{tabular}{|c|c|c|}
\hline Hoyrup-Sogn $\quad \ldots \ldots \ldots \ldots \ldots \ldots \ldots$ & 8 & Gaarde \\
\hline Arrild-Sogn $\ldots \ldots \ldots \ldots \ldots \ldots \ldots$ & $14^{1 / 2}$ & (1) \\
\hline$\ldots \ldots \ldots \ldots \ldots \ldots$ & 30 & , \\
\hline Brons $\ldots$ & 41 & . \\
\hline Reisbye $\ldots \ldots \ldots \ldots \ldots \ldots \ldots$ & $11^{3 / 4}$ & * \\
\hline Hvidding $\quad \ldots \ldots \ldots \ldots \ldots \ldots \ldots$ & 17 & " \\
\hline Vester Vedsted & $4^{3} / 4$ & " \\
\hline Roagger $\quad \ldots$. & $10^{1 / 2}$ & . \\
\hline Vodder $\ldots \ldots \ldots \ldots \ldots \ldots \ldots \ldots$ & $14^{1 / 2}$ & 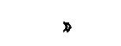 \\
\hline Seem $\ldots \ldots \ldots \ldots \ldots \ldots \ldots \ldots \ldots \ldots$ & $2^{1 / 2}$ & , \\
\hline og Spandet-Sogn $\ldots \ldots \ldots \ldots \ldots \ldots \ldots$ & 4 & , \\
\hline
\end{tabular}

hvilke forrette og præstere sædvaanlig Arbeide og Liverance ved samme med Jords Tilkiorsel ved Dæmningen og Sluserne, Haand-Arbeide, Bygnings-Tommers, Molle-Steenenes og Told-Kornets transport, dog sidste ey længere end til Tonder eller Hayer; Tags og Reebs Anskaffelse til Molle-Huuset, med videre, som de ere skyldige, naar de $i$ Tide dertil vorder beordret. 
Hoveriet er her noget nærmere specificeret end hidtil. "Tag og Reb « betyder strå og halmreb til tækning. Iøvrigt har hverken fru Outzen eller hendes forpagter Jes Lassen været særlig strenge med udnyttelsen af hoveriet.

I overensstemmelse med kontrakten betalte Jes Lassen sin afgift med halvdelen i sølvmønt, halvdelen i danske bankosedler. Men ved en forordning af 28 . febr. 1788 blev der $i$ hertugdømmerne indført en ny Specie-mønt, som skulle være den eneste gangbare, og da Jes Lassen til majdag 1789 kom med halvdelen af pagtsummen $\mathrm{i}$ de nye sølvmønter og halvdelen i danske bankosedler som sædvanligt, ville fru Outzen ikke modtage de sidste. Da de ikke kunne blive enige, klagede hun til amtet og hævdede, at de danske pengesedler ikke mere var god gangbar mønt, fordi hun derved tabte 11 skilling på hver daler. Amtet afgjorde sagen til hendes fordel, men Jes Lassen indankede sagen for overretten, som også gik ham imod ${ }^{25}$.

De havde også andre mellemregnskaber. Der er bevaret en morsom regning fra Jes Lassen for udlæg, han har haft:

\section{REGNING}

Paa hvad jeg for S. T. Fru Cancelie-Raadinde Outzen i Lygum Closter har udlagt i Aaret 1792.

Til S. T. Herr Provst Ramus i Brøns for

6 Aars Tiende a 6 Mark ................. 36 M. 8 Sk.

Til Herr Orgenist Holm 5 Skp. Rug a Skp. 24 Sk. . . $7,7,8$,

Jordemoder Løn $\ldots \ldots \ldots \ldots \ldots \ldots \ldots \ldots \ldots \ldots, 1$,

For de Fattige $\ldots \ldots \ldots \ldots \ldots \ldots \ldots \ldots \ldots \ldots \ldots, 4$,

Grund Leie for Gruben Møllen $\ldots \ldots \ldots \ldots \ldots \ldots \ldots$; ,

Til en Brandsted i Hawerward, 1 Skp. Rug ....... 1 , 8,

Den samme 1 Skp. Malt ................... 1 , 2 ,

En Egte til Apenrade for Samme ............ 1 , 12 ,

For den Samme hendtet ved Havet 2 Læs Materialer .. 2 s

57 M. 14 Sk.

Brøns Malle d. 14. Decbr. 1792.

Jes Lassen Mollere4.

I al sin korthed âbner denne regning os et indblik $i$ en svunden tid. Fru kancellirådinden har naturligvis ikke haft brug for jordemoderen $i$ sin alderdom, men denne agtværdige kvinde var en kommunalt ansat sembedsmand «, til hvis løn enhver måtte bidrage. Provsten har måttet vente på sin løn i 6 år, enten fordi man mente, at han havde råd til at vente, eller fordi man havde 
glemt ham, og han har været for beskeden til straks at kræve. En ildebrand klarede det gamle landsbyfællesskab på den måde, at grundejerne hjalp med at forsørge de skadelidte og få ejendommen bygget op igen. Alt dette måtte hvile på ejeren og ikke forpagteren.

Det fremgår ligeledes indirekte af denne lille regning, at fru Outzen har haft en god indtægt af sin malle. Hendes afgifter har ikke været stort mere end 500 rdlr., og hendes indtægt var 1130 rdlr. Vedligeholdelsen påhvilede forpagteren, men han har naturligvis ikke påtaget sig mere end det nodvendige, selv om han beholdt forpagtningen ud over de aftalte 12 år. Alligevel har fru Outzen i 1804 set sin fordel ved at udbyde mollerne til salg på auktion. Kornpriserne var gode, det var vandmallernes guldalder ${ }^{20}$; de to møller i Brøns måtte kunne indbringe en sum, som afkastede større rente end hendes årlige fortjeneste. hvortil kom, at hun så var fri for alle bryderier.

Den 13. aug. 1804 blev der da afholdt auktion på møllen. Salget omfattede både arvepagts-vandmøllen og ejendoms-vindmøllen, beboelseshuset, udskænkningen, alle udhusene og de tilhgrende landerier. Køberen skulle søge godkendelse hos rentekammeret. Betalingen skulle erlægges i slesv.-holst. courant daler, de forste 4000 til mortensdag samme år, de næste 4000 til mortensdag 1805, halvdelen af resten af købesummen til mortensdag 1806. Den anden halvdel af restsummen kunne blive stående som 1. prioritet $i$ møllerne. Sælgeren forbeholdt sig en dags betænkningstid til at tage mod budet. Det mindste bud skulle være 20.000 daler, og under 50 daler blev intet bud antaget.

Så begyndte budene at falde. Hans Nicolaysen fra Logumkloster bød 20.000. Kancelliråd Holst på Trøjborg bød ham over med 100. Nicolaysen lagde 50 på. Holst søgte at ryste ham af sig ved at springe $350 \mathrm{op}$. Nicolaysen lagde 50 på. Sådan fortsatte de, den ene sprang, den anden tog det mindste tilladte skridt ad gangen. Det var som en kamp mellem springeren og bonden $i$ et skakspil. Bonden kan blive dronning ved længe nok at rykke et skridt frem. Sådan gik det her. Hans Nicolaysen fik møllen for 22.000 daler. 


\section{Jacob Nicolaysen.}

Hans Nicolaysen tog ikke selv bolig på møllen. Hans søn Jacob optræder meget snart som bestyrer eller ejer. Kort efter giftede han sig med Maren Degn fra Brøns, og så tog han med vældig energi fat på at genrejse den forfaldne molle. Alt ialt of rede han de første år op mod 10.000 rdlr. på reparationer og nybygninger, dertil medgik hans egen fædrenearv og hans kones medgift på 3000 rdlr. Han gjorde $i$ høj grad brug af tvangsgæsternes pligt til hoveriarbejde og kom derved ud $i$ en treårig krig med Hviding herreds bønder.

Det er naturligt, at hoveriarbejde af den art, der her er tale om, tårner sig op i korte perioder, for derefter at hvile i lang tid, så pligten næsten glemmes. Nu havde der været en forpagter, som havde forsømt vedligeholdelsespligten gennem mange år: møllen var ganske forfalden, og af samme grund havde bønderne været fri for pligterne. Det er desuden fristende at prøve, hvor langt man kan gå, når der kommer en ny ejer. På den anden side må en ny energisk ejer have gjort alt $i$ stand så hurtigt som muligt, og så vokser pligterne til det uoverkommelige.

Der var naturligvis visse aftaler. Fra 1801 har man en afgørelse om en retfærdig fordeling mellem sognene. Da Brøns sogn lå nærmest ved møllen, skulle mølleren først alarmere Brønserne, når det drejede sig om mindre tjenester eller nødstilfælde, f. eks. isgang eller oversvommelse. Det skulle så ved lejlighed udlignes med de andre sogne. Tre mands håndtjeneste blev vurderet lige med en kort ægtkørsel på indtil to mil. En lang ægtkørsel, f. eks. til Haderslev, regnedes lige med 4 korte. Iøvrigt skulle arhejdet fordeles mellem sognene som følger:

\begin{tabular}{|c|c|c|}
\hline Brons & 20 & vogne \\
\hline Rejsby & 8 & " \\
\hline Hvidding . & 12 & r \\
\hline Vester Vedsted & 3 & \\
\hline$\ldots \ldots \ldots \ldots \ldots \ldots \ldots \ldots \ldots$ & 10 & > \\
\hline Roager & 7 & $\$$ \\
\hline Spandet og Seem $\ldots \ldots \ldots \ldots$ & 3 & , \\
\hline Hojrup $\ldots \ldots \ldots \ldots \ldots \ldots \ldots$ & 4 & , \\
\hline Skærbæk $\ldots \ldots \ldots \ldots \ldots \ldots$ & 21 & s \\
\hline 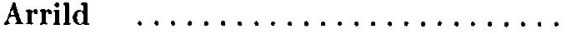 & 9 & 》 \\
\hline
\end{tabular}

Men dermed er intet sagt om den faktiske størrelse af hoveriet; 
det er kun forholdstal. Vi har også navnene på de 573 bønder, som i 1806 var hoveripligtige ${ }^{24}$.

Det første år, 1805, byggede Nicolaysen slusen og den lange bro op fra grunden. I Mandbjerg skov købte han dertil noget egetommer og andet træværk. I den anledning fik sognefogeden $i$ Brøns den 5. jan. ordre fra husfogeden til at sende 10 firspændige og 93 tospændige vogne til Mandbjerg efter egetømmeret og 22 tospændige vogne efter det andet. Sognefogeden i Brøns skulle foretage fordelingen af kørselen og holde register over hele hoveriet. Den 23. febr. skulle 12 vogne til Fole og 8 til Hygum for at afhente egetømmer og bogeplanker, som var købt der. Den 21. maj skulle der hentes 5 læs fyrreplanker i Højkro i Emmerlev sogn og 30 læs egeplanker i Fole "saa snart Sæden er lagt«. 16. juni skulle der hentes et læs tømmer i Mandbjerg. Den 2. juli skulle 2 vogne til Aabenraa efter 2 fyrrebjælker, en vogn enten til Aabenraa, Ballum eller Misthusum efter 2 tønder tjære, en vogn til Tønder efter en bjælke, en vogn til Løgumkloster efter en rambuk. Desuden skulle der daglig møde 6 mand for at bryde den gamle sluse ned og hjælpe med at nedramme pæle til den nye, máske skulle der endda siden møde flere. Den 2. aug. gives der ordre til, at der daglig skal køre 3 vogne med ler fra Ulleruplund til at fylde omkring slusen. Det kan ikke pá forhànd beregnes. hvor mange læs der skal til ialt. Foruden kusken skal der på hver vogn en mand med til at læsse ${ }^{27}$.

Allerede den første af disse ordrer vakte forståeligt nok bøndernes forfærdelse. Den 19. febr. skriver de til kongen gennem rentekammeret for at få at vide, hvor vidt deres pligter går. De vil ikke være prisgivet møllerens vilkårlighed. "Han går svanger med store Planer, som skal udfores med vore Hesle og Vogne, med vore Hænder og i vort Ansigts Sved «. Han kan kalde på dem i den travleste såtid eller høsttid, han kan sende dem til fjerne steder efter uhyre læs, hente uhyre utilhuggede træblokke hjem, blot for at han også kan få spånerne til sit køkken osv. Det er også urimeligt, at præster, sognefogeder og sandemænd, der sidder på de såkaldte frigårde, skal være fri for byrderne, når de dog er møllegæster.

Rentekammeret ønsker den 3. marts en erklæring i sagen, men forst den 1. juni afæsker husfoged Lorenzen Nicolaysen en så- 
dan. Han billiger ganske, at bønderne fár nærmere oplysninger om rækkevidden af deres pligter, men synes, at deres forlangende er en mistænkeliggørelse. Det ville stride mod hans pligter ikke at gøre den forfaldne molle i stand. Foreløbig er det dog kun slusen. Materialerne dertil har han købt på de nærmeste pladser, og han har ladet bonderne hente det ved vintertid. De er på ingen måde prisgivet hans vilkârlighed, og ordrerne udgår jo gennem husfogeden ${ }^{28}$.

Inden der er kommet svar pa bøndernes forste ansøgning, sender de en ny den 28. juni; de beder om at blive fri for hoveriet $i$ hoslettens tid. Amtmanden forlanger Nicolaysens erklæring dertil. 10. juli klager de over, at de ikke har fảet svar, og nu er høsletten der. 15. juli svarer Nicolaysen, at han ikke har besværet dem med kørsel i pløjetiden og gerne stadig vil tage hensyn til dem, men han kan ikke give dem helt fri, da slusearbejdet nodvendigt skal udføres ved sommertid. Amtmanden giver mølleren ret, men to dage senere erklærer bønderne: "Hvis vi alene skal takke Møllerens Skånsel for, at vi roligt kan indsamle vore Markers Frugt, så nåde os Gud!" De anmoder om, at hele sagen má blive retsligt undersøgt, og amtmanden berammer et retsmøde til den 2. august.

Men inden det er kommet sa vidt, begynder bonderne at strejke. Nicolaysen klager over, at en række gårdejere ikke har sendt 14 mand til at nedramme pæle. Amtmanden befaler dem at sende folkene ufortøvet eller finde sig $i$, at arbejdet bliver udført på deres regning. $O g$ den besindige husfoged Lorenzen er helt ilter: "Nu gâr Brønserne dog for vidt. Selv om der også er nogle urolige og forstyrrede Hoveder mellem dem, havde jeg dog ikke troet, at Flertallet ville følge dem og oven i købet trække Rejsbyerne med..." Amtmanden beordrer eksekution hos en lang række mallegaster, som for deres udeblivelse skal betale hver 8 skilling om dagen, fordoblet hver fjerde dag, indtil de opfylder deres pligt. Men oproret breder sig, og den 30 . juli skriver husfogeden til Nicolaysen, at han skal leje folk $\mathrm{i}$ stedet for de udeblevne fra $\mathrm{V}$. Vedsted. Husfogeden skal nok lægge pengene ud. Mølleren skal føre bog over dem, der kommer, og leje folk for dem, der udebliver. Slusearbejdet må ikke standses.

Endelig kommer retsdagen den 2. august, hvor det viser sig. 
hvem der er oprorets bagmænd. Amtmanden giver molleren ret i hele sagen, og bagefter kommer regnskabet. Ialt havde der manglet 84 karle og nogle vogne. Det takseres til 66 rdlr. 14 sk., som de skyldige har mâttet betale foruden deres boder. Og endelig den 10. aug. slutter sagen $i$ første omgang med den besked fra rentekammeret, at man ikke har fundet nøjere bestemmelser om hånd- og spandtjenesten til Brons mølle ${ }^{\star}$.

1806 vil Nicolaysen ordne baghullet, hvor vandet bag hjulene mere og mere huler jorden ud. Der skal rammes pæle ned og fyldes op med sand, jord og ler bagved. Det kan ikke på forhånd siges, hvor mange folk og vogne der skal til, men der bliver forlangt daglig 6 vogne med kuske og 6 arbejdere med spader og skovle, som skal arbejde efter møllerens anvisning. Da har bønderne jo nok fået at vide, at selve mollehuset skulle ombygges det næste år, og efter det nedslående svar, som de fik på deres forrige ansogning, sender de d. 29. okt. 1806 en ny skrivelse til kongen, hvori de beder om at få bestemte regler og grænser for hoveriet. Det er en lang og meget veltalende skrivelse med 5 bilag.

"Vi tror uden Pral at kunne hævde, at vi horer til de lydigste og mest trofaste Undersåtter, over hvilke Deres Kongelige Majestæt regerer og spreder Lykke, Tilfredshed og Velsignelse. Uden at knurre bærer vi med villig Lydighed de Byrder, som Allerhøjstsamme pálægger os som Statsborgere, og fuldforer med største Fornøjelse den Undersâtspligt, som hviler på os, idet vi er overbevist om, at den bedste og viseste Landsfader regerer over os, og han forlanger ikke mere af sine lydigste Born end af andre, og ikke mere, end der er nødvendigt for hele Statens Vel«. Således begynder de på tysk, men det falder så let i oversættelse, at det tydeligt nok er tænkt pá dansk. De har naturligvis haft en sagfører.

De klager over, at de ikke har kumnet fä fastsat nogen regel eller grænse for hoveriet. Sá ofte mølleren fløjter, skal de danse. Han henter tommer hjem fra de fjerneste steder, tilmed utilhugne blokke, for at han kan fyre med affaldet i sin husholdning. Og hvem kontrollerer, hvad han bruger tømmeret til? Og kan han forlange, at de også skal hente rambuk, tjære og kløvede sten? Han forlanger også meget håndarbejde. Når åen fryser til om 
vinteren, opbyder han et stort antal folk til at slå isen i stykker, og det på en årstid, da det er vanskeligt at få daglejere. Desuden bliver de forurettet ved deres egen mølle. Fremmede bliver forst betjent, eller de får malet ved vandmøllen, mens tvangsgæsterne bliver henvist til vindmøllen, der ikke maler nær så godt.

Bønderne har atter $\mathbf{i}$ denne skrivelse været så udiplomatiske at nævne, at sognefogeder og sandemænd ikke burde være fri; de har jo endda de største gårde. Derfor fremkommer herredets sandemænd med en protest mod at blive blandet ind i striden. De har altid været fri for hånd- og spandtjenesten. - Der kom ikke noget svar på denne klage, og i dette tilfælde kan det måske siges, at intet svar også er et svar. Dermed endte dramaets anden akt.

Men da var den tredie allerede under udvikling. I sommeren 1807 skulle selve møllehuset bygges op fra ny. I den anledning beordrede husfogeden: Hos Hans Hansen i Fole skal hentes 18 læs egetræ og planker med to heste for hver vogn. To læs skal hentes på blokvogn med 4 heste for og et læs med 6 heste. I Aller mølle skal hentes en mølleaksel på blokvogn med 6 heste for. Hos Nis 'Thomsen i Mandbjerg skal hentes 28 læs træ med to heste for hver vogn. Hos møller Brademann i Tønder skal hentes 3 læs planker. I Skærbæk eller Burkal skal hentes 23.000 mursten. hvortil der vel skal bruges 154 vogne. - Den 18. juni udgår der desuden ordre til, at der skal leveres 80 traver tag til den nye møllebygning. Det skal leveres den 4. og 5. juli, og leverancen fordeles mellem sognene.

Da sender bønderne en ny ansøgning, denne gang stilet til kronprinsen. De minder om tidligere skrivelser, som de ikke har fảet svar på, beder atter om normer for hoveriet og nu navnlig om at blive fri for at levere de $\mathbf{8 0}$ traver tag, som de ikke er forpligtet til at yde. Niels Andersen Pinborre og Peder Lassen har skrevet under på bøndernes vegne.

Lorenzen er ikke i tvivl om, at bønderne skal levere tag til mollen, og Nicolaysen oplyser, hvornår de sidst har gjort det. Det står desuden i arvefæstekontrakten. Det ved bønderne også godt, og mange sogne har allerede leveret deres part, så Pinborre og Lassen har nok ikke noget mandat til at skrive under på alles vegne. Heller ikke denne ansøgning synes at være besvaret.

Men nu er det værste overstået for denne gang. I 1808 bliver 


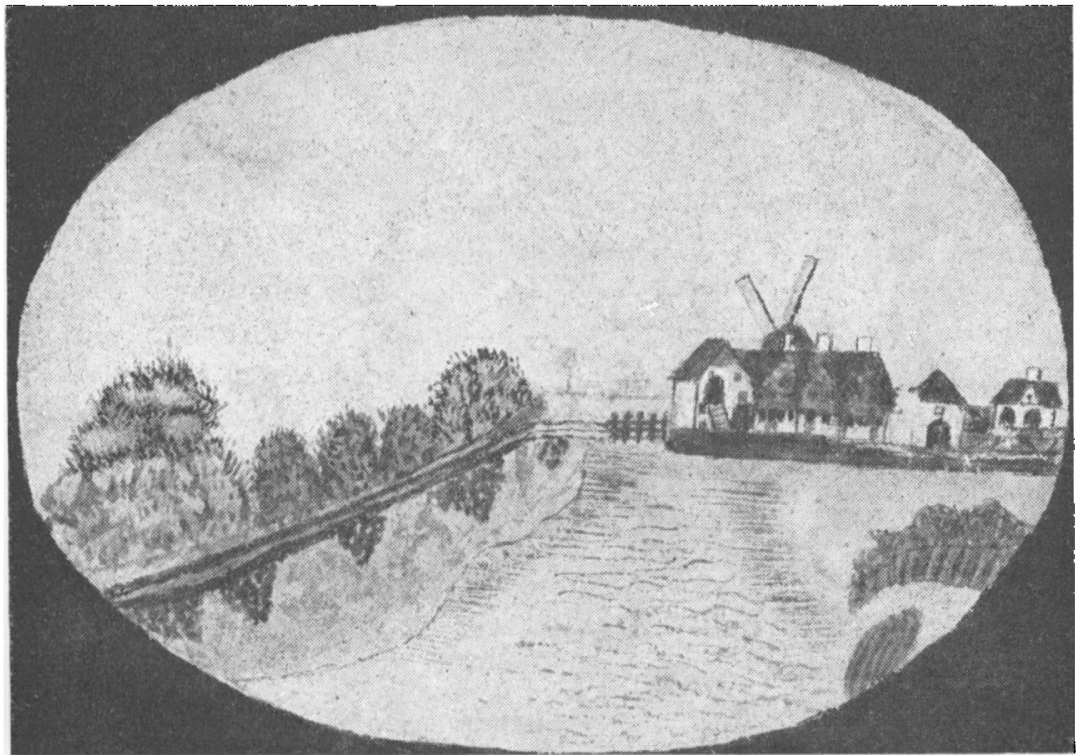

Brфns mфlle o. 1830, farvelagt tegning, ingen initialer.

der kun rekvireret vogne til transport af 15 td. rug, som Nicolaysen har solgt. Men der kommer et lille efterspil. Blokvognen, som skulle hente molleakslen i Aller, gik i stykker. Vognmændene, som bønderne havde lejet til transporten, tog hjem. Nicolaysen måtte have nye folk fra Haderslev og ville have sit udlæg godtgjort. Der blev retssag om det, men vi ved ikke, hvordan det endte.

1820 var der atter betydeligt hoveriarbejde, og 1838 skulle bønderne levere 30 traver rugting til reparation. Derefter mangler der efterretninger, indtil báde malletvangen og hoveriet blev afløst $i$ 1853. Da blev værdien af hoveriet af vurderingsmændene, som var bønder, ansat så lavt, at man vel kan betragte det som bondens hævn over møllen.

Da Nicolaysen i 1808 havde făet mollen genopbygget, tog han for alvor fat på at male. Der skulle også tjenes penge. Gælden var steget til over 30.000 rdlr. I renter og afgifter skulle han betale ca. 1000 rdlr. om året, og det lykkedes ham tillige $i$ løbet af nogle gode år med høje kornpriser at bringe gælden ned til det halve. 
Men så kom statsbankerotten i 1813, afslutningen på Napoleonskrigene $1814 \mathrm{og}$ derefter et kolossalt fald på alle landbrugsprodukter. Det blev umuligt at betale mere af på gælden, og afgifterne var beregnet efter helt andre tider. Jakob Nicolaysen gav dog ikke straks op. Han søgte at konsolidere sin bedrift ved at forbedre og udvide møllens landbrug. 1820 gjorde han dæmningen i stand. Året efter bad han amtet om at få hele åen og de tilstødende bække renset op. Det skete også.

Men under alt dette lå der et tryk på den ærekære mand, fordi han ikke kunne svare enhver sit. Dag efter dag græmmede han sig derover. Herredsfoged Wardenburg siger rent ud, at han dode af græmmelse, kun 40 år gammel. Det var den 23. marts 1823.

Derefter gik det ikke bedre for hans enke, der sad tilbage med 6 små børn. 1824 bad hun om eftergivelse af halvdelen af afgif . ten til kronen, men fik afslag. Hun foreslog da rentekammeret, at kronen afkøbte hende arvepagts-vandmøllen og den private vejrmolle, men fik atter afslag. Det endte da med, at kreditorerne drev hende til konkurs.

Af kreditorer var der mange, men de fleste var repræsentanter for arvingerne efter fru Outzen. De udbød mollen til offentlig auktion 28. aug. 1826. I auktionsprotokollens $\$ 4$ nævnes alle de «Instrumenter og Redskaber, som horer til Mollernes Brug «. Denne liste over det løse inventar gengives omstående $\mathrm{i}$ bilag 3 .

Efter kreditorernes ønske skulle møllerne sælges hver for sig, og vejrmøllen blev først opbudt for 1000 rdlr., men hvem ville købe en vejrmølle, når der lå en vandmølle ved siden af, som måske kom på andre hænder? De to møller blev da opbudt samlet for 5000 rdlr. Men da der stadig ikke faldt noget bud, blev auktionen standset, og en ny blev ansat til 26. sept. Da blev begge møllerne atter udbudt for 2500 rdlr. Lüdick Jacobsen fra Brede mølle og A. C. Møller fra Logumkloster bød forsigtigt hinanden over, indtil Lüdick Jacobsen pludselig sprang fra 3200 til 4000 , hvorved Møller tabte pusten. Summen blev omregnet til 6400 rbd. i sølv. Det er ejendommeligt at sammenligne denne auktion med den foregående i 1804. Dengang var det inflationstid, og summen var høj. Nu er det deflation, og i første omgang melder der sig ingen købere til den fastsatte mindstepris. En måned efter 
udbyder man møllerne til den halve sum; det var en tid, hvor der var penge at tabe.

Men hvordan gik det Maren Nicolaysen, da hun således var drevet fra hus og hjem? Da hun var blevet enke og sad med 6 uforsørgede børn, brød det hele sammen for hende. Hun havde lidligere været en god husmoder, men nu så hun ingen udvej og begyndte at drukne sine sorger i flasken. Der var udskænkning på møllen, sã hun havde ikke langt til brændevinen. Hun solgte et stykke jord og nogle møbler på et tidspunkt, hvor hun ikke kunne svare enhver sit. Måske vidste hun ikke, at dette var ulovligt. Kreditorerne, hvor af flere var familiens gamle venner, så først gennem fingre med det, men da del ved auktionen viste sig, at de fik så ringe dækning for deres tilgodehavende, tog de denne sag op pany, og mente tillige, at det havde været ulovligt, at Maren Nicolaysen havde søgt at sælge møllen til staten. Hvordan sagen endte, oplyser de gamle dokumenter ikke, men det gør Brøns kirkebog. Maren Nicolaysen døde 16. sept. 1828, 44 år ganmel. Hendes sag var indanket for en højere domstol, som undertiden med synlig strenghed hjemsøger fædrenes synder på børnene, her dog moderens. Det sidste vi nemlig hører om familien Nicolaysen i Brøns er dette, at datteren Anna døde 1880 som fattiglem. En gammel kone i Brøns har fortalt mig, at hun godt kunne huske "Anna Klojsen ", snavset, pjaltet og luset. Hun boede på "Kalmar slot «, som man spøgefuldt kaldte sognets fattighus. Når trangen til brændevin sved alt for stærkt, gik hun til naboerne og tiggede en snaps. Byens børn var bange for hende, og mødrene sagde: Tænk, hun er født på Brøns mølle!

\section{Hans Christian Jacobsen.}

Den nye ejer af Brøns mølle, Lüdick Jacobsen, havde det ægte møllerblod i årerne fra sine forfædre ${ }^{30}$. Han var født på Brede molle 1774, blev gift 1801 med sin kusine Anna Thomsen fra Sdr. Vollum, der døde efter 9 års ægteskab. De havde tre sønner, Hans Christian Jacobsen, f. 1802, til hvem faderen købte Brøns mølle, Thomas Ludevig, f. 1807, som overtog Brede mølle, og Andreas Ludevig, f. 1809, til hvem faderen 1836 købte Hellevad molle. Man kan vist med rette kalde dette et møllerdynasti.

Da nu Lüdick Jacobsen havde overtaget Brøns mølle, måtte 
han straks i gang med de opgaver, som i reglen mødte en ny ejer, nemlig reparation af huset og bedriften og forsvar for molleprivilegierne mod dem, som troede at kunne tiltage sig friheder overfor en ny mand. Præsterne var blandt dem, der var ivrigst efter at bryde mølletvangen, men Jacobsen fik amtmanden til at udstede et "mandatum publicum", hvori molletvangen blev indskærpet. Det skulle oplæses på kirkestævne, så det kan ikke have været præsterne ubekendt. Alligevel måtte Jacobsen føre proces mod tre af dem. Han måtte ligeledes gennem en hel række processer angående stævning $i$ åen og det rette flodmál i mølledam$\operatorname{men}^{81}$.

Med hensyn til reparationerne var det den lange bro, som først stod for tur. Både Lüdick Jacobsen og sønnen Hans Christian var til stede ved ombygningen, men lidt efter lidt overtog sønnen både møllens og landbrugets drift, selv om hans fader vedblev at stå som ejer helt til 1852 . Ved en lang række jordhandeler udvidede $\mathrm{H}$. C. Jacobsen møllens landbrug, og dertil måtle der skaffes passende bygninger. 1832 byggede han de stald- og ladebygninger, som delvis står endnu, i midten en lang staldbygning og i hver ende af den en fløj ud mod syd. Fløjene var hver på 8 fag, stalden på 24. Det kostede ham over 1000 rdlr.

1844 var det stuehuset, som stod for tur. Men her var baggrunden den glædelige, at der var kommet familie til. 1833 var han blevet gift med Anna Winther fra Hjerndrup. Deres ældste søn, Lydik Jacobsen (i kirkebogen Lydick) blev født 22. sept. 1835, den næste Hans Michael, den senere ejer af Kærmark, blev født 15. maj 1839. Dertil kom efterhånden en stor husførelse og et stort folkehold. Altså måtte det gamle stuehus, som Andreas Andersen havde bygget, og som han havde været så stolt af, rives ned. Det nye hus blev 15 fag stort og bygget så højt op, at soklen er to trin højere end vejen på dæmningen; det gamle hus lå vel en meter lavere. Men da huset skulle være længere end det gamle, rev Jacobsen to fag ned af sydfløjen på avlsbygningen for at give plads, og i stedet byggede han to flaje ud mod nord, hver på 6 fag, sâ avlsbygningernes grundplan derved kom til at ligne et bredt $\mathrm{H}$. Det nye stuehus kostede 1500 rdlr.; det blev bygget med stor omhu og står endnu.

Denne travlhed med at skabe et større landbrug og rummeli- 
Lithdck Jakobsen, $1774-1867$.

gere bygninger såvel til dette som til beboelse, betyder dog ikke, at selve mølleriet blev forsømt, eller at det ikke gav ret meget at bestille. Denne side af virksomheden afspejler sig blot ikke i tilsvarende grad i de bevarede dokumenter. Men der er på møllen gennem mere end hundrede år ført bog over formalingen fra år til år. Heraf skal der til belysning af møllerivirksomheden gives et lille uddrag. Af de normale år angives højst hvert femte, men $i$ krigstiderne hvert år. Tallene angiver hele tonder a $100 \mathrm{~kg}$.

$\begin{array}{crrrrrrr}\text { År } & \text { Hvede } & \text { Rug } & \text { Skørt } & \text { Byg pillet } & \text { Malt } & \text { Boghvede } & \text { Kilowatt } \\ 1836 & 25 & 4343 & 2499 & 1712 & 1060 & 543 & \\ 1841 & 19 & 4554 & 2052 & 1801 & 1219 & 610 & \\ 1846 & 156 & 3999 & 2639 & 1271 & 1009 & 638 & \\ 1851 & 151 & 3852 & 2368 & 1276 & 800 & 540 & \\ 1856 & 118 & 3110 & 2379 & 1588 & 583 & 629 & \\ 1861 & 80 & 2741 & 2902 & 1315 & 382 & 760 \\ 1866 & 72 & 2716 & 2740 & 1283 & 371 & 495 \\ 1871 & 38 & 2322 & 2720 & 1241 & 361 & 439 & \\ 1876 & 580 & 2507 & 2506 & 635 & 254 & 190\end{array}$




\begin{tabular}{crrrrrrr}
\hline Ar & Hvede & Rug & Skørt & Byg pillet & Malt & Boghvede & Kilowatt \\
1884 & 572 & 1742 & 3109 & 515 & 233 & 196 & \\
1907 & 1700 & 2668 & 5696 & 236 & 59 & 9 & \\
1910 & 478 & 3376 & 4692 & 162 & 92 & 16 & 824 \\
1914 & 663 & 2422 & 2564 & 129 & 30 & 9 & 994 \\
1915 & 985 & 529 & 1772 & 457 & & 10 & 1050 \\
1916 & 2344 & 1772 & 1698 & 1020 & & & 1131 \\
1917 & 2373 & 1472 & 1433 & 1183 & & & 1049 \\
1918 & 826 & 1650 & 1223 & 496 & & & 1640 \\
1919 & 270 & 2959 & 1123 & 491 & & & 2276 \\
1920 & 954 & 3085 & 2014 & 0 & & & 1416 \\
1925 & 96 & 1889 & 3144 & 0 & & & 1311 \\
1930 & 80 & 2371 & 5152 & 34 & & & 8053 \\
1935 & 96 & 2717 & 3317 & 47 & & 7745 \\
1940 & 361 & 2960 & 1731 & 303 & & 6326 \\
1941 & 288 & 3367 & 1276 & 202 & & & 3202 \\
1942 & 10 & 2115 & 945 & 501 & & & 8080 \\
1943 & 23 & 2711 & 1960 & 378 & & 13020 \\
1944 & 15 & 2975 & 1421 & 135 & & & 14670 \\
1945 & & 2890 & & 90 & & &
\end{tabular}

Disse tal viser os ikke blot, at mølleren i Brons altid har haft noget at bestille, men de fortæller os også noget om befolkningen og dens levevilkår. Man ser, at folk omkring ved århundredskiftet er hørt op med at brygge deres øl selv, og at de på samme tid blev ked af hoghvedegrød. Man lægger også mærke til nedgangen for byggens vedkommende, men hver gang der kommer en verdenskrig, kommer man igen i tanker om, at der er noget, der hedder byg. Med skørtkornet er det omvendt. I de gode tider bruger man meget korn til kreaturfoder, men når krigen kommer, skal kornet bruges til menneskeføde. Rugen er mest konstant; den betyder det daglige brød, som man altid skal have. Hveden kommer mere og mere i brug i det 19. årh., men her gør konkurrencen med de store industrimaller og med udlandet sig stærkt gældende, en konkurrence, som forsvinder når krigen spærrer mellem landene. Formalingen af hvede viser derfor stærke udsving. For rugens vedkommende må man dog lægge mærke til, at selv om den betyder det daglige brød, er der en betydelig nedgang $i$ halvtredserne. Det betyder ikke, at man gik på smalkost med hensyn til rugbrødet, men at mølletvangen blev ophævet, så bønderne i Hviding herred kunne lade deres brødkorn male, hvor de ville. Derved led Brøns mølle et føleligt tab. Endelig viser den sidste 
kolonne produktionen af elektricitet gennem den overskydende vandkraft. Det første tal gælder dog ikke året 1910, men 1913.

Fra dette udblik over et århundredes virksomhed vender vi tilbage til $\mathrm{H}$. C. Jacobsen. Trods hele hans stigende arbejdsområde var han dog stadig kun forpagter af Brøns mølle. En vis ændring i dette forhold var vel indtrådt i 1841 ved en deklaration mellem de tre brødre, som deres fader havde opfordret dem til at oprette. De skulle hver som arveforskud have $6000 \mathrm{rdlr}$. cour. Da Andreas havde fået Hellevad malle til en værdi af 7000 rdlr. cour. og Thomas Brede mølle til en værdi af 5000 rdlr. cour., skulle Andreas til Thomas forrente $1000 \mathrm{rdlr}$. cour. indtil deres faders død. Og da H. C. Jacobsen havde fået Brøns mølle til en værdi af $12000 \mathrm{rdlr}$. c., skulle han forrente $6000 \mathrm{rdlr}$. c. til faderen indtil dennes $\mathbf{d a d}^{25}$. En halv snes år senere blev der endelig skrevet købekontrakt mellem fader og søn, først den 3. marts 1852 en mere privat kontrakt, undertegnet af Lüdick Jacobsen og to vitterlighedsvidner. Den fastslog, at mollen skulle koste 12000 rdlr. c. $(19200$ rbd. sølv), hvoraf halvdelen var betalt ved det nævnte arveforskud, mens resten blev stående som 1. prioritet. Dernæst blev der den 18. nov. oprettet en lovformeligt stemplet købekontrakt, hvori dog kun de 6000 rdlr. c., som blev stående i møllen, blev omtalt som salgspris. Det skete formentlig for at spare på stempelpengene, men det fik senere skæbnesvangre følger. - Nu var $\mathrm{H}$. C. Jacobsen endelig ejer af møllen også formelt, og 1866 udbetalte han den nævnte prioritet, så han havde mallen gældfrit. Året efter døde hans fader.

Halvtredserne blev en meget bevæget tid med store opgaver. At den lange bro og slusen, som havde stået siden 1827, igen trængte til fornyelse, var kun, hvad man kunne vente. Ombygningen fandt sted 1858. Nej, mere væsentligt var det, at molletvangen 1852 blev afløst. Liberalismen for som en stormvind hen over landene og bortfejede privilegier og gjorde alle mennesker frie og lige. I kongeriget blev der ikke givet nogen erstatning til møllerne, fordi der ikke var nogen egentlig molletvang. Men der måtte ikke bygges nye moller $i$ de forste 10 år; de gamle mollere måtte i denne overgangstid bygge filialmoller for at konsolidere sigs3.

I hertugdømmerne var forholdene noget anderledes, fordi der 


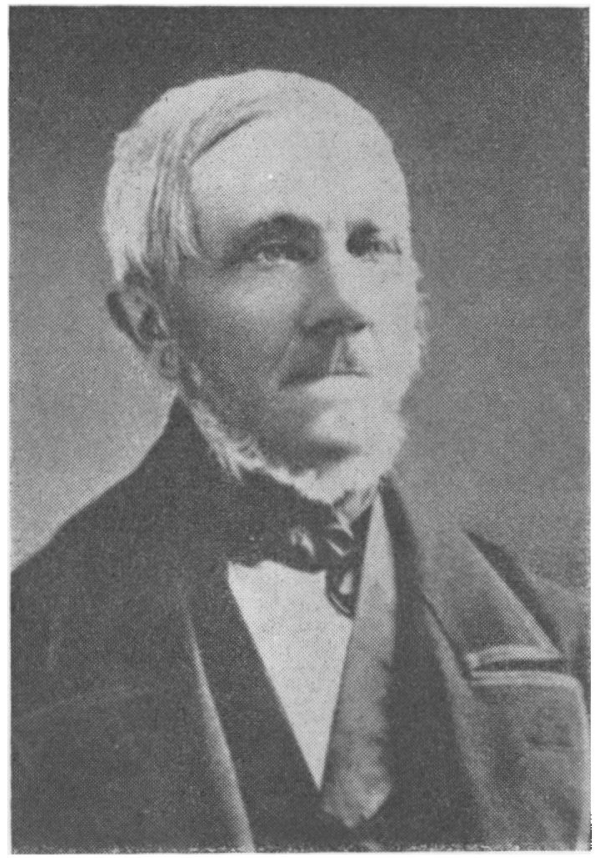

Hans Chr. Jucobsen,

18(1)2-1892.

her var en klart udtalt molletvang, og fordi den danske grundlov ikke kom til at gælde i Slesvig. Kongen udstedte den 21. nov. 1852 en "Forordning angaaende Malletvangens Ophrevelse i Hertugdømmet Slesvig * og forbeholdt sig at forelægge den i næste forsamling af $\gg$ Vore troe Provindsialstænder", hvorefter han ville overveje, om der var noget at ændre i den. Den var altså et provisorium. Den bestemte, at mølletvangen skulle ophæves fra 1 . jan. 1853. Den blev oplæst på kirkestævne i Brons kirke d. 12. dec. Da har H. C. Jacobsen jo nok været i kirke.

Forordningen bestemmer, at mollerne skal have erstatning for ophævelse af molletvangen. Er de ikke tilfredse med erstatningen, kan de gå rettens vej, eller kongen vil overtage mollen til den pris, de har givet for den. Men desuden bliver mollenæringen i grunden ikke fri. Der skal sages koncession til oprettelse af nye moller og betales en af gift på 25 rdlr. for hver kværn i disse.

Størrelsen af erstatningen skulle bestemmes på grundlag af en laksation af det tab. som ophavelsen af molletvangen påforte 


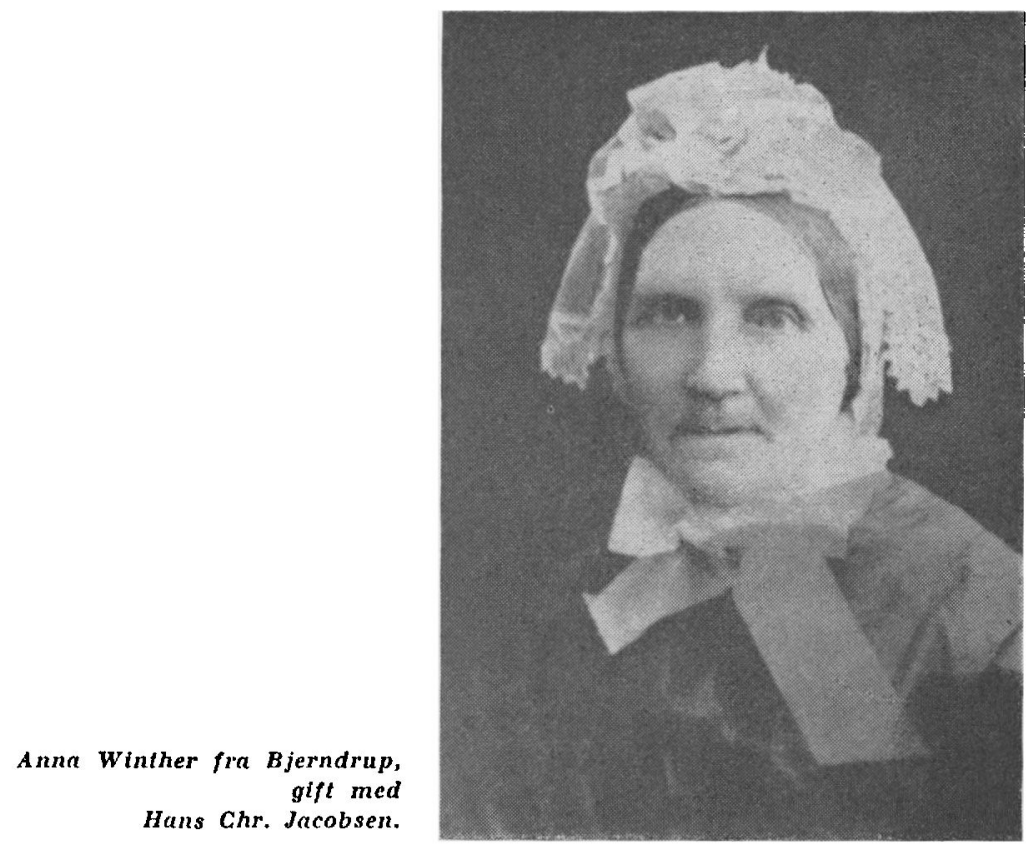

møllerne. For Brøns molles vedkommende fandt taksationen sted 18. marts 185.3. Fire bønder med herredsfogeden i spidsen udg.jorde kommissionen. Den opgjorde tabet således:

Med undtagelse af halvdelen af beboerne i Hojrup sogn var alle haderslevhusiske beboere i Hviding herred tvangspligtige til Brøns malle. Efter folketællingen i 1845 anslog man deres tal til ca. 5000. Hver person konsumerede årligt $2 \mathrm{td}$. rug og malt, altså 10.000 td. Møllerens told heraf, en tyvendedel, var 500 td., som kostede $7 \mathrm{mk} .8$ sk. cour. Møllerens indtagt var altså her 1250 rdlr. Sâledes gik man videre til de andre kornsorter, noget blev sat for højt, noget for lavt, men Jacobsen protesterede foreløbigt ikke mod, at man ansatte hans indtægt af toldkornet til $1460 \mathrm{rdlr}$. cour. Når nu mølletvangen blev ophævet, ville Brøns molle antagelig miste $3 / 5$ af sin formaling, altså 936 rdlr. cour. Men så ville der ikke slides så meget på møllen, og man behøvede mindre arhejdskraft. Herfor fradrog man 100 rdlr., altså facit 836 rdlr.

Nu mente kommissionen, at ikke blot molletvangen, men også 
hoveriet var ophævet ved den nye forordning. Deri havde den måske ret, men i virkeligheden stod der ikke et ord om hoveriet. De to ting var imidlertid således sammenknyttet $i$ tankegangen, at ingen fandt på at protestere på dette punkt. Man opgjorde den årlige værdi af hoveriet til 111 rdlr. 40 sk. c. Det samlede tab kapitaliserede de til 23.695 rdlr. 40 sk. og anslog møllens værdi i handel og vandel til 33.000 rdlr.

Men alt dette fik ingen som helst betydning, når man læste $\$ 4$ i forordningen. Der stod, at erstatningen ikke måtte overstige fjerdedelen af møllens værdi, udregnet efter den sidste købesum med tillæg af den til $4 \%$ kapitaliserede canon.

Det var så uheldigt, som det kunne være. Kun tre dage før forordningens udstedelse havde $\mathrm{H}$. C. Jacobsen og hans fader underskrevet den lovformelige købekontrakt, i følge hvilken møllen kostede 6000 rdlr. Naturligvis fremdrog Jacobsen deklarationen mellem de tre brødre, ifølge hvilken han havde givet 12.000 rdlr. for mallen, og vurderingsmændene forstod nok situationen, men det var ikke let at redde den. Den årlige afgift eller canon var 454 rdlr. 12 sk. c. Kapitaliseret efter $4 \%$ var det 11356 rdlr. 12 sk. Hvis man nu kunne regne møllens købesum til 12.000 rdlr., hvad højere instanser måtte afgøre, ville vurderingssummen blive 23.356 rdlr., og ellers 17.356 rdlr. 12 sk. En fjerdedel heraf ville blive henholdsvis 5839 rdlr. 3 sk. eller 4339 rdlr. 3 sk., og en af de summer ville altså blive det højeste, som Jacobsen kunne få $i$ erstatning.

Da han fik det at vide, protesterede han. I en lang skrivelse til regeringen ${ }^{34}$, gennemgår han $i$ enkeltheder taksationsforretningen. Han regner sin normalindtægt under mølletvangen ud til 4023 rdlr., og går ud fra, at han kun vil beholde lidt over en femtedel af mollegæsterne, hvorfor tabet ved mølletvangens ophævelse vil blive 3170 rdlr.

Særlig interessant er hans opgørelse af hoveriets værdi, der er anført som bilag 4. Selv om det på flere punkter må anses for at være topnotering, giver det dog en sagkyndig mands oversigt over, hvilke arbejder der gennem århundreder har skullet udfares for at holde en gammel vandmolle vel ved magt.

Men den grundige dokumentation hjalp ikke noget. Man gik frem efter lovens bogstav uden hensyn til, at den sidste salgspris 
for Brøns mølle var en pris mellem brødre. Man tog det hensyn at lægge den egentlige salgsum på 12000 rdlr. til grund, og den deraf følgende godtgørelse på 5839 rdlr. 3 sk., som omregnet $i$ rigsmønt blev 9342 rdlr. 48 sk., blev tilkendt Jacobsen på den måde, at hans årlige mølleskyld eller canon blev nedsat fra 720 rdlr. 38 sk. rigsmont til 346 rdlr. 67 sk. $^{24}$. Men dermed var sagen ikke endt. Når de 12.000 var blevet lagt til grund for beregningen, mens den stemplede kontrakt lød på 6000 , var der altså betalt for lidt i stemplingsgebyr, og det gav et eftersmæk $i$ form af en regning fra herredsfogeden på 1665 rdlr. rigsmønt $i$ mefterstemplingsgebyr $*$. De blev betalt fire dage efter, men sikkert ikke med glæde.

H. C. Jacobsen havde svært ved at affinde sig med dette resultat. Han mente at have tabt over 3800 rdlr. årligt og fik til erstatning en lettelse på 373 rdlr., hvis kursværdi endda kun var $5 / 8$ af de tabtes. Han tøvede med at skrive under, men regeringen pressede på, og endelig den 4 . okt. 1857 satte han pennen til papiret og frafaldt alle yderligere krav.

Men hans sind fandt ikke ro. Han var $1859 \mathrm{i}$ audiens hos ministeren for Slesvig og fik lov til at indsende et andragende om fritagelse for canon. Det blev ikke bevilget. Han indsendte den ene ansøgning efter den anden og fik stadig afslag. 1861 stilede han et bønskrift til kongen ledsaget af en ny vurdering af mollen, som var foretaget af "Hr. Rigsraad Krüger fra Bevtoft", som selv var molleejer. Det nyttede heller ikke noget. 1866 og 1870 forsøgte han hos de tyske myndigheder med samme resultat. Canon var nu beregnet til 420 mark. Men efterhånden blev den betragtet som en ren grundbyrde og som sådan endelig afløst $i$ halvfemserne, hvorefter mollen var selveje.

Der er imidlertid ved hele denne trængselshistorie den lyse side, at Brøns molle klarede sig trods det lidte tab, ja klarede sig bedre end alle de konkurrenter, som opstod på de nye friheders grund. Aen var Brøns mølle tro. Det kunne hænde, at de omliggende vindmøller i stille vejr kom til Brøns mølle for at få deres kunders korn malet. Også kunder udenfor distriktet kunne på sådanne dage finde den gamle vandmolle.

H. C. Jacobsen nøjedes dog ikke med at skrive bønskrifter for at afbøde de tab, som den nye tid bragte ham. Han tog aktivt fat 
på at gøre brug af de nye vilkår. Med den stigende konkurrence havde han ikke brug for både en vandmalle og en vindmølle $i$ Brons, og han søgte derfor i 1858 om tilladelse til at flytte vindmøllen til Roager. Derved oplevede han et slemt sammenstød med kontorius. Det slesvigske ministerium sendte sagen tilbage til erklæring hos amtmanden, som sendte den til herredsfogeden, der skulle skaffe oplysninger om stedet, vejforholdene, og om der var andre møller $\mathrm{i}$ en mils omkreds. Så kunne han give ministeriet den ønskede erklæring, hvori han ogsă pegede på Jacobsens tab og på det uløselige forhold mellem vandmallen og vindmøllen. Tabet kom ikke sagen ved, svarede ministeriet, det afgarende var, om der var mølletrang i Roager. Det blev amtmanden lidt stødt over og svarede, at der ikke var nogen definition af ordet $\$$ molletrang " $i$ den slesvigske lovgivning, hvorfor han havde holdt sig til den kongerigske. Det tyggede ministeriet på i 16 måneder og traf så den salomoniske afgorelse, at Jacobsen måtte flytte mollen til Roager, men den skulle betragtes som en ny malle, hvoraf der skulle betales 25 rdlr. af hver kværn. Hidtil havde Jacobsen betalt 19 rdlr. 19 sk. $i$ afgift af vindmollen. En selvstændig malle i Roager ville kræve 4 kværne. Han svarede da, at han ikke kunne gå ind på de stillede betingelser og forlangte at få sin bevilling til vindmollen i Brøns kasseret. Mod dette andragende kan der selvfølgelig ikke nævnes noget at erindre, siger amtmanden overrasket, da han videresender svaret til ministeriet. Det tog også pusten fra ministeriet, der whavde troet at komme Jacobsens $\emptyset_{n}$ ske i Møde", men da det ikke syntes at være tilfældet, gav de ham lov til at flytte møllen og nøjes med en årlig afgift på 20 rdlr. Høfligt svarede Jacobsen, at han for nogen tid siden ville have taget mod dette tilbud med tak, men nu var der allerede påbegyndt en ny molle i Roager på kongerigsk grund. Så blev hans koncession på vindmøllen endelig kasseret 8. maj $1860^{20}$.

Det var kromanden i Roager, som skulle til at bygge molle. Men det var ogsâ Jacobsen selv. Han benyttede sig af den kongerigske lovgivning af 1852 , og da han snart efter fik kromanden overtalt til at lade være, var han ene om pladsen. Selve møllen kostede omtrent 4000 rdlr., et beboelseshus 1000 rdlr. Ved dette arbejde havde H. C. Jacobsen god hjælp af sin ældste søn, Lydik 
der nu var 24 ar gammel. Han var medhjælper ved håndværket, og det er ham, der har fort regnskabet for hele arbejdet ${ }^{24}$.

Men Roager mølle blev ikke noget helt smertefrit aktiv for slægten Jacobsen. Forpagterne skiftede tit, og den kunne ikke bære nogen stor forpagtningsafgift. Det endte med, at $\mathrm{H}$. C. Jacobsen i 1887 gav den til sine to sønner, Lydik og Hans Michael i forening. 15 âr senere solgte de den til Fr. Clausen fra Nordborg for 11750 mark. "Det føltes som en Lettelse , skriver Lydik Jacobsen i dagbogen, „for den havde påført os mange Vanskeligheder og megen Besvær med de mange Forpagtere".

H. C. Jacobsen var ikke blot optaget af det timelige. Børnenes danske undervisning lå ham meget på sinde. En tid havde han $\mathrm{H}$. Tjellesen Schmidt som huslærer. Da det var meningen, at Lydik skulle være moller, mâtte han se sig om efter et landbrug til Hans Michael. 1861 købte han en række kratbevoksede parceller i Brøns kær, hvor senere gården Kærmark blev bygget.

I en lang ârrække var han kirkeværge, og det ikke blot af navn. Under restaureringen af kirken $1850-55$ var han på ingen måde indstillet på tidens mode med imiteret egetræsmaling, marmorering osv. og vekslede flere skrivelser derom med biskoppen. "Havde han levet i disse Tider", skriver Carsten Petersen i "Sønderj. Årb. " 1939, s. 214 * ville han rimeligvis have restaureret sin kirke pâ linje med moderne videnskab og kunstopfattelse".

1867 døde den gamle Lüdick Jacobsen i Brede og omtrent samtidig hans søn Thomas. Derved kom der endnu mere velstand til Brøns mølle. H. C. Jacobsen var også selv ved at komme op i årene, og da han tænkte på at overlade møllen til sin søn, købte han 1868 en toft $i$ Brøns, hvorpå han byggede et dejligt hus og anlagde en smuk have. Der levede de to gamle mollerfolk i en række gode år, til de begge døde 1892, H. C. Jacobsen d. 18. marts 90 är gammel, og hans hustru Anna, fodt Winther, den 5. juni, 79 år gammel. Huset, som efter nogle ârs forløb blev købt af Poul Møller, er nu overtaget af kommunen til lærerboliger.

\section{Lydik Jacobsen.}

Lydik Jacobsen, som overtog møllen efter sin fader 1. jan. 1868, blev en af de store skikkelser, ikke blot i møllens historie, men også i egnens og landsdelens. Han blev 9. maj samme år gift 


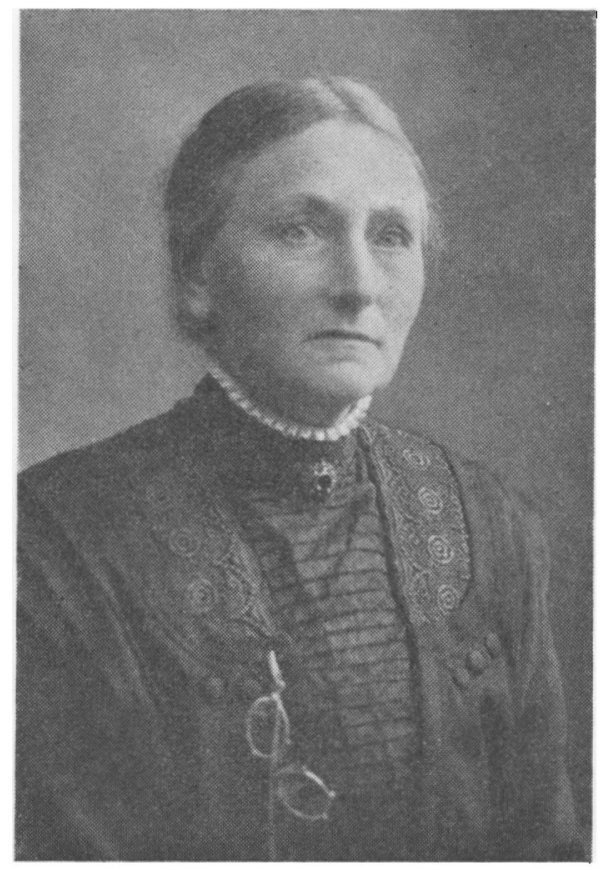

Annu Nicoline Ellung fru IIjerting, gift med

Lydik Jacobsen.

med Hanne Sophie Lautrop fra Skjoldager. De fik i deres korte agteskab tre børn, Hans Christian, som senere fik Slotsmøllen i Nyborg, men 1917 emigrerede til Amerika, Harald Egidius, som senere blev gårdejer i Kongsted ved Fredericia, og datteren Hanne Sophie, som blev gift med møllebygger Niels Peter Petersen, der kort efter købte Havnemøllen i Fredericia ${ }^{30}$.

Lydik Jacobsen overtog mollen og landbruget til en pris af $60.000 \mathrm{kr}$., kornbeholdningen for $2492 \mathrm{og}$ kreaturerne for 8000 . Det har dog nok kun været en foreløbig vurdering, som han siden i sin dagbog har omregnet til danske penge. Seks år senere blev der skrevet kontrakt; da nævnes der en købesum på 21.000 daler preussisk cour. til en kurs af $56.000 \mathrm{kr}$. Desuden en årlig livrente til forældrene på 540 daler pr. c. Men de 21.000 daler var at betragte som arv og skulle ikke udbetales. For den anden søn, Hans Michael, havde H. C. Jacobsen sørget ved at bygge gården Kærmark og henlægge et betydeligt areal til den. 


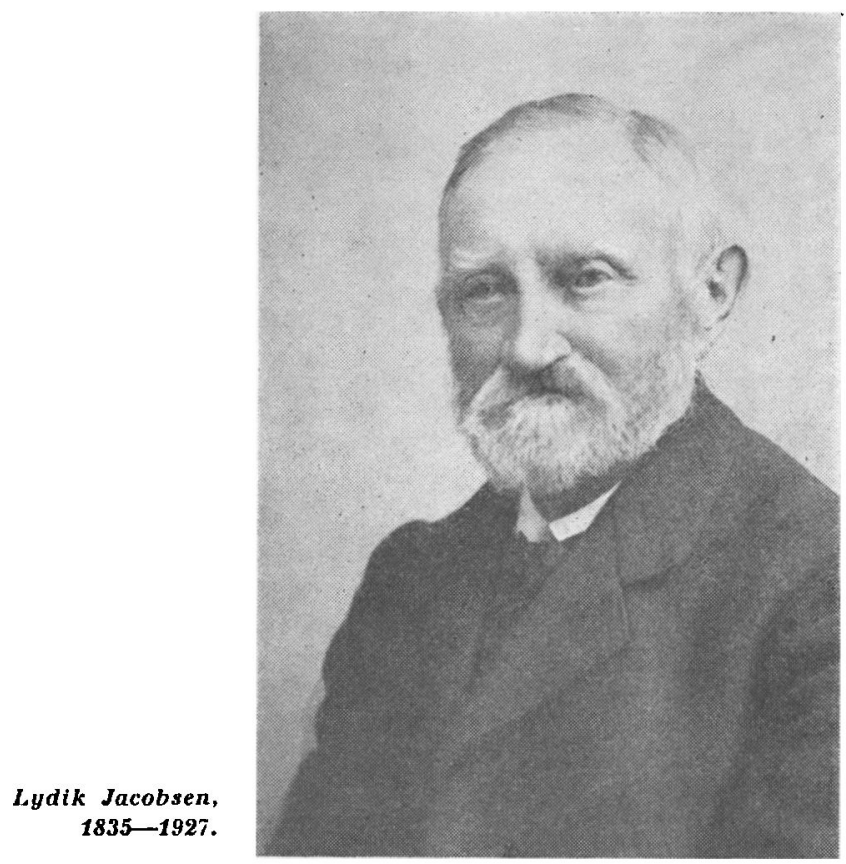

Noget af det første, Lydik Jacobsen tog fat på, var en udbedring af vejene til møllen. Det påhvilede ganske vist ikke ham, men kommunerne og de enkelte beboere, men han havde interesse $i$, at det kom $i$ orden, og derfor sluttede han kontrakt med beboerne om at gøre det. Snart derefter tog han fat på større opgaver. 1870 fik han efter forhandling med Brønserne åløbet vest for møllen reguleret, så møllen bedre kunne komme af med bagvandet.

Året efter regulerede han tilløbet pà overraskende måde. Han havde fundet det overflødigt at have en mølledam på mere end $30 \mathrm{tdr}$. land. Han lod da ganske simpelt vandet løbe ud af den og gravede i den sydvestlige kant af den en kanal, gennem hvilken vandet kunne løbe til møllen, mens de store arbejder stod på. Og i den nordøstlige del af den udtørrede dam byggede han en dæmning, bag hvilken mølledammen skulle indsnævres i fremtiden. Derved indvandt han 15 ha. jord, som 1872 blev tilsået med græs. 
Mens kanalen blev gravet mod sydvest, og demningen blev bygget mod nordust, benyttede Lydik Jacobsen lejligheden til at ombygge mollen. Han havde tankt på turbiner, men de var endnu ikke så udviklede, at de tilfredsstillede ham, sa han besluttede sig til at indlægge overfaldsvandhjul $\mathrm{i}$ stedet for de gamle underfalds. De gamle hjul var anbragt udenfor mollen i selve áløbet, men han anbragte de nye inde $i$ møllen og ledede vandet ind over dem gennem en kanal. Det krævede gennembrud af murene, for at vandet kunne komme báde ind og ud, og vældige nye arbejder med fundamentering og anden sikkerhed. Endelig byggede han den sydlige ydermur helt op i hojde med malesalen. I flere måneder havde han 5-6 mand $i$ arbejde ved kanal og dæmning, og i lang tid 3 mollebyggere foruden. Arbejdsfolkene havde han pa kost, så der var noget at forestả for hans hustru. Og selv havde han det store landbrug at passe. Den 12. aug. satte de det forste nye vandhjul $i$ gang og holdt $i$ den anledning et lille gilde. Men fire dage senere viste det sig, at den unge energiske mand ikke ustraffet kumne byde sig selv alt. Da han om aftenen var omme på den gamle malekumme, besvimede han og faldt i vandet, men heldigvis slog han sig ikke og kom til sig selv igen og kravlede op og gik til sengs. Det blev ham en lære.

Den 13. dec. 1872 døde hans hustru af barselfeber og lod ham ene med tre små børn. Det blev en tung tid for ham, men det meget krævende arbejde oy ungdommens lyse sind kom ham til hjælp, og da han 29. sept. 1874 giftede sig påny med en datter af konsul Ellung i Hjerting, Anna Petra Nicoline Ellung, en søster til Hans Michaels hustru, mildnedes den dybe sorg. De fik lov at leve og arbejde sammen i over 52 år. I dette ægteskab kom der fire børn, Ivar Axel, som var svag fra fødslen og døde på Nyborg sygehus 1914, Aage, som blev født 29. april 1877, og som siden overtog Brøns mølle. Endvidere datteren Anna Nicoline, der blev gift med Hans Aage Knudsen fra Visby Hedegaard, og endelig sønnen Asger, som faldt i den første verdenskrig 1914.

At være mellem dobbelt ild er ikke behageligt, men at være mellem dobbelt vand kan også være slemt. Brons mølle har altid ligget mellem dobbelt vand og har altid máttet kæmpe for at tøjle de kræfter, som skulle drive hjulene rundt. Da nu den formindskede dam lå pæn og glat ovenfor mollen. var det tid at tage fat 
på »baghøllet « nedenfor. Lydik Jacobsen rammede pæle ned og sikrede bredderne med faskiner i 1874 . Det slog ikke til. 1880 fyldte han hullet med store træer, der blev holdt fast af nedrammede pæle og jernbøjler. 1888 igen. 1897 igen. 1898 igen. En stadig kamp med det afbrugte vand:

Men også det tilflydende vand var vanskeligt at styre. Den udtørrede dam måtte drænes, Lydik Jacobsen lagde selv alle drænrørene. 1883 blev den nye dæmning gennembrudt, sâ vandet måtte ledes til møllen gennem den søndre kanal, og det var svært at få det i orden igen. 1889 blev han klar over, at den nye mølledam alligevel var for lille. Han ledede da atter vandet sønden om gennem kanalen og byggede en ny dæmning, men en lille stump af den gamle dæmning fik dog lov at stå midt ude $i$ den nye dam som en ø til svanerne; det tænkte han også pâ. I februar 1895 var det så streng en vinter, at mølleslæden kunne køre over isen til Rømø. Mølledammen og dæmningen var tilfrosset dybt ned. Men den 12. marts pressede vandet sådan på under isen, at det lettede både isen og de med denne sammenfrosne dæmninger, så vandet banede sig vej under frostlaget. Da måtte man lade hele den gamle dam løbe fuld af vand, så man atter kunne male, og imens kørte man jord over isen og fyldte $i$ hullet og nedrammede spunspæle som ekstra sikring. Så skar vandet hul ved siden af frislusen og broen, og man måtte atter tømme den gamle dam og lade vandet løbe i den nye. Derved blev der for stort tryk på den nye, næppe færdige dæmning, så den brast igen, og det nye hul var større end det første. Så blev åen spærret og vandet ledet gennem kanalen, mens man med stort besvær reparerede dæmningen og rammede pæle ned $i$ den frosne jord. Den 25. april var man færdig efter 6 ugers kamp, og siden har dæmningen skikket sig vel.

Men alt dette var kampene med det normale vand. Endnu værre var kampene mod det sunormale ", stormfloderne fra vest og regnfloderne fra øst. I juli 1877 var der på een gang stormflod fra vest og regnflod fra øst, så man på begge sider af dæmningen kunne fiske hø op, det som vesterhavet skyllede ind vestfra, og det som regnfloden skyllede med østfra. Lydik Jacobsen kunne huske den store isflod i 1839, da Vesterhavets isskodser jævnede alle havens træer med jorden. 1894 gik havet trods landevejsdæmning og jernbanedæmning atter op til møllen og stod en alen 
over bunden af friskøtterne, og i 1916 var det inde i møllens kælder.

Men den værste flod, Lydik Jacobsen oplevede, kom dog fra øst. Det var den 3. aug. 1879. Det var lummervarmt og stærk blæst fra øst. Om aftenen begyndte det at lyne og tordne, og regnen skyllede ned. Endnu efter midnat var den gamle mølledam tør, men så kom vandet væltende østfra. Der var en strækning på 200 meter af dæmningen, hvor denne var en halv snes $\mathrm{cm}$ lavere, så vandet kunne strømme over her, hvis den gamle mølledam blev fyldt. Men det slog ikke til. Vandet strømmede over i hele dæmningens længde. De måtte beskytte møllen med sandsække, ellers var vandet løbet ned $i$ undermøllen og havde sprængt den indefra. Mellem stuehuset og avlsbygningerne var der en passage på 4 meters bredde; der skyllede vandet over vejen og ned mellem bygningerne, underminerede stuehusets gavl, så den væltede tillige med et par fag af sidemuren. Vandet væltede en $12 \mathrm{~m}$ lang og $2 \mathrm{~m}$ høj brandmur. Brosten, mursten og store træer blev begravet i dybe slugter, og sand blev skyllet ovenover. Nedenfor møllen lå sandet på sine steder $60 \mathrm{~cm}$ tykt på engene. En hel måned gik, inden man fik ryddet nogenlunde op efter denne ulykke, og så kom Lydik Jacobsen til at tænke på ordene $\mathrm{i}$ den gamle arvefæstekontrakt om de ulykker, som ikke kunne afværges, og som kunne berettige molleren til moderation i pagtsummen. Han lod skaden taksere; det blev for de større poster 4250 mark, og så søgte han om eftergivelse af canon for de følgende 8 år. Men han fik til svar fra regeringen i Slesvig, at han efter loven om afløsning af grundbyrder af 3 . jan. 1873 ikke længere var at betragte som arvefæster, men selvejer, og den gamle pagtsum var at betragte som en grundbyrde. Så vidste han det.

Om arbejdsvilkårene $i$ denne periode skriver han i 1880: s Karleløn var i denne Periode $320 \mathrm{Kr}$., Pigeløn $120 \mathrm{Kr}$. Vi kørte Møllevogn til Skærbæk, Rejsby, Vodder og Havervad to gange ugentlig «. Rugen kostede på denne tid 171/2 kr. pr. td. Det var gode tider for møllerne ${ }^{36}$. Selv så svære tab, som den store vandflod medførte, lod sig bære, uden at økonomien blev rokket.

1887 blev møllen påny ombygget, der blev sat en ny etage på og trempelværk ovenpå. Der blev muret 31 dage. Det kunne gøres for 120 mark. Hver gang Lydik Jacobsen blev klar over, at noget 
kunne forbedres, undersøgte han sagen nøje, og var af den grund på mange studierejser $i$ ind- og udland. 1894 indbyggede han siloer. De var inddelt i 8 celler, som hver kunne rumme 120 tdr. korn.

Også med hensyn til stuehuset foretog han stadig forbedringer. 1895 brød han de gamle kviste ned og byggede den nye tværbygning ved den nordre ende af huset, satte trempelværk over det ovrige og tækkede det hele med tagpap i stedet for strå. En del af stuehuset fik derved to etager, og der blev indrettet 5 værelser ovenpå.

Den 1. jan. 1907 bortforpagtede han mølleriet til sin søn Aage for 3000 mark årlig. Han begyndte at tage reb i sejlene, men han lagde ikke op. Han vedblev selv at arbejde med landbruget, som altid havde haft hans kærlighed. 1910 byggede han stuehus (aftægtshus) til sig selv. Der var et lille slip mellem stuehuset og stalden, men for at få plads nok til et gavlhus måtte der dog nedbrydes 4 fag af staldbygningen. Her blev da det nye stuehus opført $i$ to etager. Samme år byggede han et hus med bolig til to arbejderfamilier i nærheden af møllen. Det var klog politik. Det var lettere at få folk, når man havde et hus, de kunne bo $i$.

1911 havde han en grundejendom på 91.58 ha. 1912 gav han byggegrund til sin broder H. M. Jacobsen, hvor denne opførte villa Solbakken til aftægtsbolig. 1. maj 1922 bortforpagtede han også landbruget til sin søn Aage, der et år før havde købt møllen og året efter også købte landbruget.

Ved arv, ved overmåde flittigt arbejde og ved streng økonomi var Lydik Jacobsen blevet en holden mand. Man ser det gennem hans evindelige stridigheder med de tyske skattemyndigheder. Men læser man hele den stak papirer, som fortæller om disse stridigheder, får man indtryk af, at det også drejer sig om national opposition.

Men der var mange andre områder end hans egne, som gennem årene nød godt af hans evner, hans udholdenhed og energi.

Syd for den udtørrede mølledam lå et stort areal, som kaldtes »Møllebjergene«; det var bakker eller klitter af flyvesand, som endnu kunne vende det hvide ud, og som stadig havde nogen tilbøjelighed til at flytte sig. Ind mellem disse bakker var der lavere steder med noget bedre jord, men til gengæld vandlidende og 
sur. Allerede omkring 1870 begyndte Lydik Jacobsen på sit arbejde for at få dette areal tilplantet. Men folk skulle oplyses og overtales, medarbejdere findes, og det tog tid. Der blev endelig dannet et plantningsselskab 1881. Flyvesandet blev tøjlet og de vandlidende steder afvandet. Nu står der på stedet en dejlig skov, som giver mangen god dagløn til arbejderne, gavntræ til bønder og håndværkere og godt udbytte til aktionærerne og mange naturglæder til egnens beboere. - Men Lydik Jacobsen standsede ikke ved Mollebjergene. Syd for lå endnu et areal, som egnede sig til beplantning, „Kalbymark«. En snes år efter at det første plantningsselskab var blevet til, var Jacobsen sjælen i et nyt, som fik navnet Kalbyskov. Disse to selskaber er siden sluttet sammen til eet, og man har fortsat med at tilplante nye arealer, så der nu er 160 ha tilplantet under fællesnavnet Brøns Skov.

Et par år før Lydik Jacobsens død overrakte de samvirkende Plantningsforeninger i Danmark ham deres store sølvbæger ved en festlighed i Grindsted, hvor man hædrede ham med navnet sSønderjyllands største plantningsmand «. På hundredårsdagen for hans fødsel blev der på en beplantet klit i skellet mellem Møllebjergene og Kalbyskov rejst en mindesten med følgende indskrift:

\author{
Lydik Jacobsen \\ Brøns Molle \\ Grundlagde Møllebjergene 1881, \\ Kalbyskov 1902. \\ Den øde Hede blev til Skov, \\ din Gerning mindes med Tak og Lov.
}

Men der var utallige andre områder, hvor han var med til at gøre en indsats for sin egn og sit land. $1876-87$ var han med i arbejdet for at få bygget banen gennem det vestlige Slesvig, den såkaldte slesvig-holstenske marskbane.

1883 oprettedes Sparekassen for Brøns Sogn med ham som formand. Før 1887 var posten kommet til Brøns fra Skærbæk. Han byggede et hus, hvori der kunne blive et selvstændigt postkontor for Brøns. Han var virksom for at tegne kapital til en dansk bank på Vesteregnen; det blev Tønder Landmandsbank, i hvis tilsynsråd han blev indvalgt fra begyndelsen.

Navnlig nød det nationale arbejde godt af hans evner. Han 


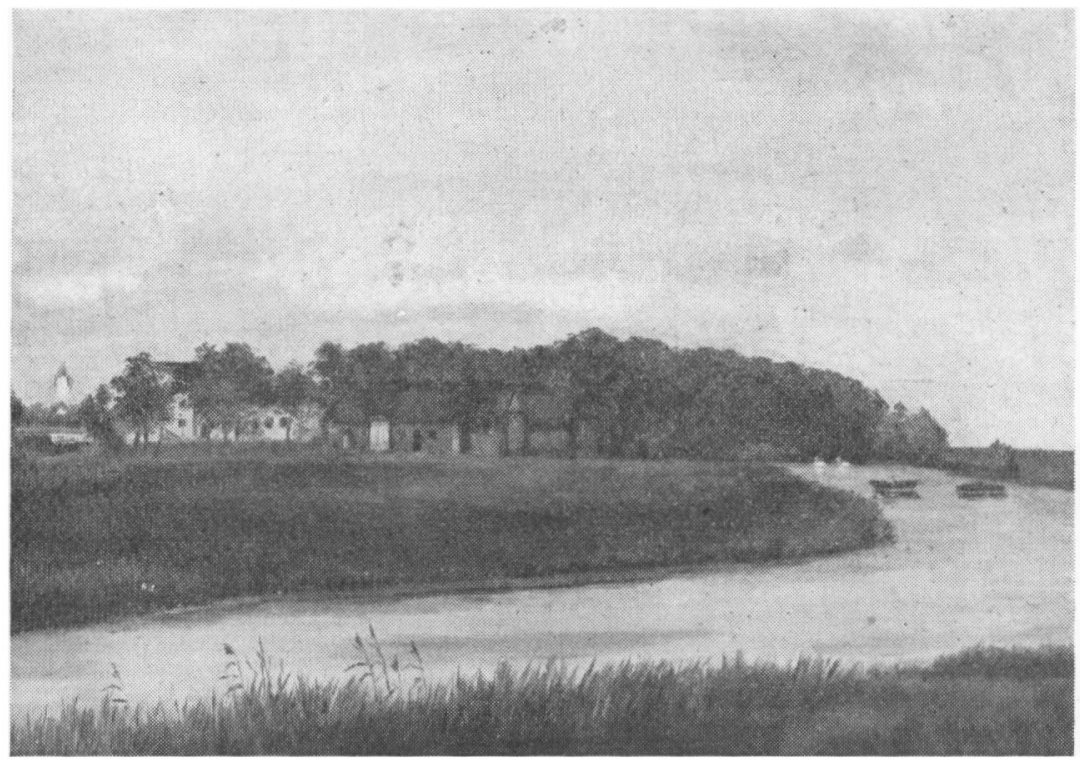

Brøns mølle med kirken i baggrunden. Maleri - formentlig kopi. L'kendt kunstner Sikkert fru tiden op mod airhundredskiftet.

stod i spidsen for oprettelsen af en dansk højskole i Brøns; den fik dog kun en kortvarig virksomhed. Den åbnede 1868, men blev lukket af tyskerne 1871. Sammen med P. Skau, Bukshave, var han i sommeren 1883 fører for de sønderjyske pigers rejse til København. Det var en prægtig tur, men stillede store krav til de to føreres talegaver.

Naturligvis måtte han betale bøder for at have taget en datter ud af kommuneskolen i Brøns og sendt hende til skole i Ribe. Naturligvis fik han sine folk udvist i Køllerperioden. Og naturligvis var han ivrig for at få bygget et forsamlingshus i Brøns. Det gik dog trægt med at få pengene samlet sammen. Huset kostede 8000 mark, da det blev bygget i 1905, og da man kun havde 3000 , måtte Lydik Jacobsen garantere for de to femtedele af resten.

Med lige så stor kærlighed deltog han i det kirkelige arbejde. Allerede 1871 blev han valgt til synoden i Rendsborg sammen med 3 andre fra Nordslesvig. "Vi udrettede ikke store ting ", siger 
han, "men hævdede dog at bruge vort danske sprog ved vore udtalelser, en ret som den efterfølgende synode lod falde«. 1882 blev han med stor højtidelighed indsat som skirkeældste $\mathrm{i}$ Brøns kirke. Han var tillige stadigt medlem af provstisynoden.

Kærligheden til kirkebygningen tog han også $i$ arv efter sin fader. Så sent som lige efter verdenskrigen, da han havde mistet sonnen Asger, havde han den tanke at smykke kirken med et glasmaleri til minde om sønnen, men siden fik han en anden plan. Det havde været hans tanke, at Aage skulle have møllen og Asger landbruget. >Men Gud ville det anderledes «, siger han. Da han 1923 havde solgt både møllen og landbruget til Aage, så han det som sin sidste opgave at rejse Asger et værdigt minde. I al stilhed begyndte han at fælde træer $i$ sin private skov og tildanne tømmer til et hus. Han lod sine egne folk lægge grunden. Men ingen vidste, hvad det var, han havde for. Forst ved rejsegildet oplyste han, at huset var bygget for Asgers arvepart, at det skulle hedde *Asgersminde * og rumme to gratis lejligheder for værdige trængende familier.

Lydik Jacobsen døde 1. febr. 1927, 91 år gammel. Ved begravelsen den 9. febr. blev hans ridderkors båret efter kisten på en fløjlspude, og efter gammel skik ved en kirkeældstes begravelse blev der skænket lys til kirken, og præsten gik på prædikestolen og indledte sin prædiken med at oplæse hans vita.

Men glasmaleriet til kirken var alligevel ikke glemt. $\mathrm{Nu}$ tog hans enke tanken op, men med den ændring, at det skulle være et minde om hendes mand. Joakim Skovgaard tegnede en skitse, efter hvilken hans søn Johan Thomas Skovgaard udførte maleriet i fuld størrelse 1931. Det blev et meget værdifuldt kunstværk, som fremstiller Jesus, der velsigner de små børn. Lydik Jacobsen havde selv valgt dette motiv. Forneden bærer det følgende indskrift: "Lader de smaa Børn komme til mig. Minde om Lydik Jacobsen, Brøns Mølle; opsat 1931 af hans Hustru Nicoline, født Fllung «. Fru Jacobsen overlevede sin mand til 30. marts 1940.

\section{Aage Jacobsen.}

Aage Jacobsen gik i skole i Brøns, siden på katedralskolen i Ribe. I sin ungdom var han på Testrup og Askov højskoler og 1905-6 på møllerskole i Dippoldiswalde. Fra 1. jan. 1907 forpagte- 
de han møllen af sin fader for $\mathbf{3 0 0 0}$ mark årlig, foreløbig for et tidsrum af 5 år. Vedligeholdelsen af møllen skulle overtages af forpagteren, mens ejeren skulle vedligeholde sluser, broer og dæmninger. Forpagteren skulle dog passe vandstanden, og hvis der kom dæmningsbrud, skulle de være halvt om skaden. Ejeren skulle købe sit privatforbrug af mel og korn til dagspris, og han skulle have møllersvendene og forpagteren på kost og logi for 300 mark om året. Ejeren påtog sig kørsel med møllevognen og al møllens kørsel iøvrigt for bestemte takster. Der skulle ved overtagelsen foretages en taksation af to sagkyndige mænd, som også skulle optage en fortegnelse over maskiner og inventar på møllen. Denne inventarliste lyder:

\section{Kalderen:}

En Exhauster (Blæser), gammel, i brugbar Stand.

1 do ny, i brugbar Stand.

\section{Malesal:}

Østre Kværn, Kunststen, Flint; do Kunststen, fransk.

Skørtkværn, ny Kunststen, fransk. Understen rhinsk.

Vestre Kværn, ny baade Lober og Underligger.

Pillesten 62" hamb. Maal.

Boghvedekværn.

Et Par Valsestole med et Par glatte Valser, et Par stumpriflede Valser.

Et Par Valsestole med et Par Skraavalser, slove, et Par skærpet i

\section{Sommer.}

En Melblandemaskine, ny.

\section{Loft:}

En Kageknuser, brugt.

Et Støvfilter, nyt.

En Forsigte, brugbar Stand.

Øverste Loft:

1 Centrifugalsigte i brugbar Stand, 2 Sæt Rammer, 2 Rammer uden Flor.

1 do i brugbar Stand, 2 Sæt Rammer med Flor.

2 Forsigter med forsænket Traadvæv.

1 Bungesigte i brugbar Stand, forslidt i Halsen. (Bunge er fabrikantens navn).

1 Bygmelssigte i brugbar Stand.

1 Rugmelssigte i brugbar Stand.

1 Rafinermaskine i brugbar Stand.

3 Decimalvægte ${ }^{23}$.

Det blev nævnt i kontrakten, at forpagteren skulle have kost 
og logi hos ejeren; han var altså ugift. Men i 1910 skete der forandringer. I dette år byggede Lydik Jacobsen som nævnt sin aftægtsbolig, for der skulle være plads til en ny familie på den gamle mølle. Den 7. sept. 1910 indgik Aage Jacobsen ægteskab med Thoma Caroline Fischer, født 5. okt. 1887 i Åbenrå som datter af den kendte kaptajn C. C. Fischer. Hun havde gået $\mathbf{i}$ skole $\mathbf{i}$ Ảbenrå, men efter konfirmationen været $i$ huset hos rektor Hoff på Sorø Akademi, hvor hun fik sit andet hjem. Hendes moder, Anna Marie Offersen, var død allerede 1888. I dette ægteskab fødtes der fire døtre: Anna Charlotte Kristine, Inger Nicoline, Tove og Ragnhild, alle med efternavnet Fischer Jacobsen.

1911 blev der foretaget en retslig vurdering af møllen på begæring af Lydik Jacobsen. Retten havde medtaget mølleejer Asmus Boisen på Tørning mølle og Jacob Steffensen fra Bevtoft mølle. De ansatte værdien til 50.000-52.000 mark og nævnte, at bygningerne var gode, men møllens maskinelle indretning var lidt gammeldags. I dette forhold skete der en forandring allerede ảret efter, da det forreste vandhjul blev fjernet og erstattet med en turbine på $35 \mathrm{hk}$. Dette medførte atter nye planer, som blev muliggjort ved en tilbygning, der allerede 1907 var blevet føjet til møllen. Der var kornloft i de tre øverste etager, men rummet i nederste etage blev i 1912 indrettet til akkumulatorrum, idet man efter anskaffelsen af den nye turbine gik $\mathbf{i}$ gang med at bygge et lokalt elektricitetsværk. Det blev $\mathrm{i}$ første omgang et jævnstrømsværk, 220 volt, som forsynede møllen og en del naboejendomme med lys og kraft. I 1919 gik man et skridt videre, nedtog også det andet vandhjul og erstattede det med en turbine på 50 hk. Under krigen var der blevet oprettet et roetørreri i en bygning vest for banelinjen, og der havde man brug for elektricitet. Værket blev da lavet om til vekselstrøm på 3000 volt, da man ellers ikke uden tab kunne sende strømmen så langt. Som følge deraf kunne også hele kvarteret mellem møllen og forsamlingshuset blive forsynet med strøm. Efter krigen blev der først truffet aftale om levering af strøm til et par lokale elektricitetsværker i Bredebro og Løgumkloster. Luftledningerne blev sammenkoblede, og de to værker kørte om dagen, mens møllen sendte strøm ind på ledningerne om natten. Da det store højspændingsværk i Åbenrå blev færdigt, opslugte det efterhånden de 


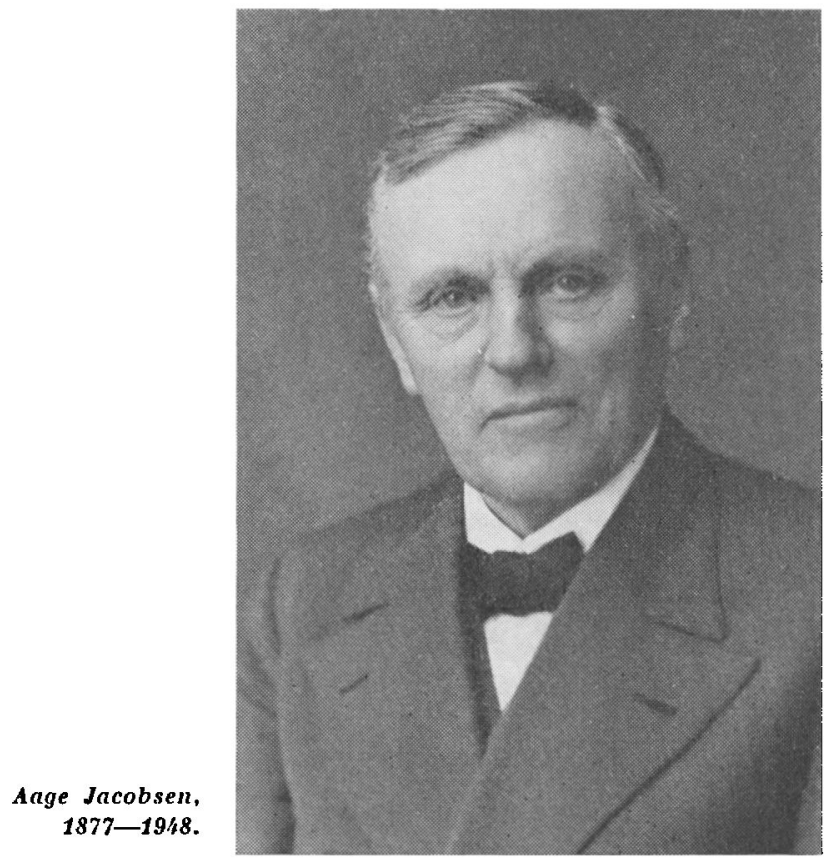

mindre værker. Det havde kraft nok, og der blev i en årrække ikke meget for møllen at gøre. Dog blev ledningerne sammenkoblede, så møllen dels kunne bruge strøm fra højspændingen, dels kunne tilbagebetale dette forbrug, når vandmængden tillod det. Under den anden verdenskrig, da brændselsvanskelighederne satte ind, steg produktionen af elektricitet betydeligt. Højspændingsværket fik brug for al den hjælp, som vandkraften kunne yde.

Da Aage Jacobsen også havde overtaget landbruget, forbedrede og udvidede han avlsbygningerne. Stråtaget kom bort, og taget blev løftet, idet der blev sat trempelværk over muren, og taget blev tækket med pandeplader. Bảde laden og kreaturstalden blev bygget større, og stuehuset blev moderniseret.

I årene fra 1907 til krigen i 1914 blev der årligt formalet 710.000 tdr. korn, hvoraf en trediedel var brødkorn og en trediedel deraf var hvede. Af foderkager blev der omsat ca. 2000 dob- 
beltcentner årligt. Der blev $i$ disse år endnu avlet en del boghvede på egnen, så en mand havde nok at bestille $i$ to-tre efterårsmåneder med at male gryn. Forbruget af byggryn gik jævnt tilbage, så der var ikke brug for mere end een pillesten, og den anden blev fjernet. Da krigsårene kom, måtte folk indskrænke sig med forskellige fødevarer, især oversøiske, og de hjemlige gryn kom atter til ære og værdighed. Produktionen steg fra 100 til $1000 \mathrm{tdr}$. byg årligt. Af malt solgtes der før krigen ca. $80 \mathrm{tdr}$. årligt. Krigen standsede møllevognen, som havde kørt rundt til de omliggende byer helt fra mølletvangens ophør. Myndighederne beslaglagde nemlig alt korn, og bønderne, som blev kaldt "selvforsørgere", måtte kun lade mindre kvanta korn male, og for disse kvanta var der $\mathrm{i}$ forvejen udstedt maleseddel. Der blev dog malet betydeligt mere, og møllersvendene tjente sig i krigsårene en formue $\mathrm{i}$ drikkepenge. Af og til kom der revision på mollen, $i$ reglen militærpersoner, der var afkommanderede for rekreationens skyld. De var i reglen sultne, så det var praktisk at begynde revisionen med at give dem et godt foder. Når de så var kommet i humør og havde fået udsigt til at få lidt med hjem til familien, gik revisionen temmelig let. De hjemlige myndigheder havde heller ikke mange fødevarer, så de fik også deres part. Således kom Brøns mølle gennem de fire krigsår uden bøder eller anden straf.

Efter krigen forandrede mølleriet sig. Der var atter ris at få, og nu efter genforeningen tillige udenlandsk mel. Ingen ville spise byggryn mere, og husmødrene ville ikke bage af den hjemlige hvede. Den sidste pillesten forsvandt og blev erstattet af en skalmaskine, der også egnede sig til fremstilling af gryn. Malt var helt forsvundet; alle købte øl fra bryggerierne. Under den sidste verdenskrig steg formalingen af brødkorn påny, i nogen grad også af den hjemlige hvede, og byggrynene fik påny en kortvarig hædersperiode.

Aage Jacobsen var mølleforpagter i 14 år. 1921 købte han møllen af $\sin$ fader for $40.000 \mathrm{kr}$. Aret efter overtog han landbruget i forpagtning, og 1923 købte han også dette for $68.000 \mathrm{kr}$. For så vidt kunne man tro, at han havde nok at gøre med sin egen bedrift, men på mange andre felter blev hans evner taget $i$ brug. I længere perioder sad han $i$ sognerådet, $i$ nogle år som dets for- 


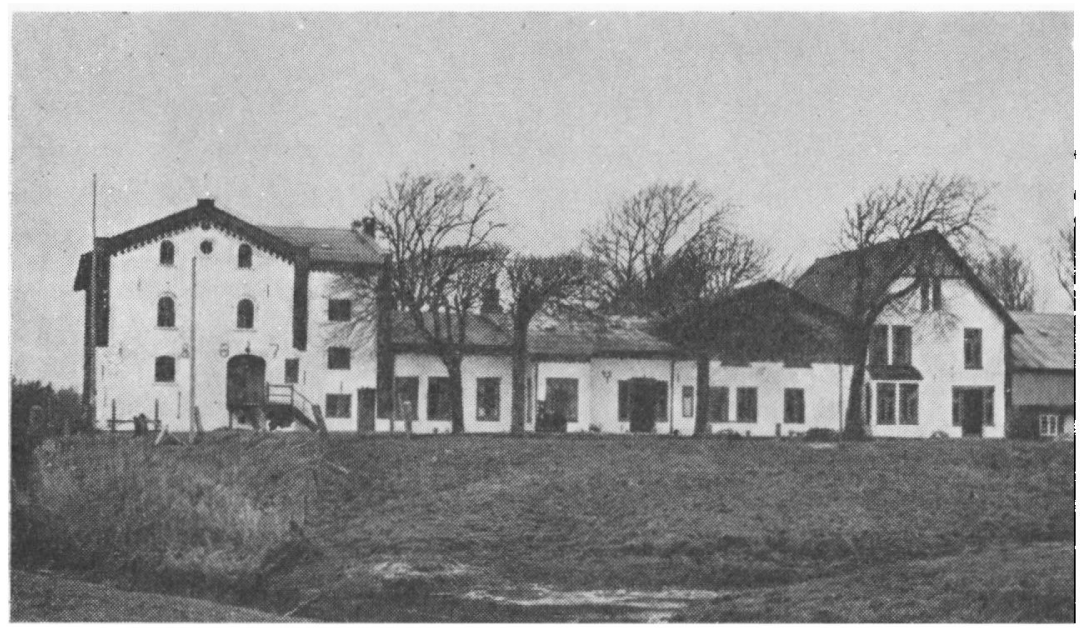

Brøns mølle $i$ Aage Jacobsens tid.

mand. Men navnlig tog han på flere områder arven op efter sin fader. Han var formand for plantningsselskaberne, sluttede dem sammen og udvidede skovarealet og ledede personligt hele virksomheden. Som faderen var han medlem af Tønder Landmandsbanks bestyrelse og tog levende del $i$ det nationale arbejde, især som tillidsmand for Sprogforeningen; da danskheden syd for grænsen vågnede, havde den $i$ ham en varm ven. Også personligt lignede han sin fader; han var jævn og fordringsløs, noget indesluttet, kunne gå længe og tumle med sine planer, indtil de var modne til at føres ud $i$ livet, eller han måtte forelægge dem for andre, som burde være medarbejdere.

Han havde en levende historisk interesse, som naturligt nok begyndte med Brøns mølle. Allerede Lydik Jacobsen havde begyndt at samle dokumenter om møllens historie og ladet folk forske $\mathrm{i}$ arkiverne. Meget lå der jo i forvejen fra gammel tid. Dette arbejde førte Aage Jacobsen videre, så der blev samlet et ret stort arkiv om møllen; det er nu deponeret i Landsarkivet i Ảbenrå. Denne historiske interesse gjorde ham også til medstifter af det lokale > Historisk Samfund for Brøns Sogn « i 1943.

Han nåede ikke sin faders og sin farfaders høje alder. En mavekræft, som ikke kunne bortopereres, kastede ham på et langva- 
rigt og smerteligt sygeleje, inden han døde 29. juni 1948, 71 år gammel.

Ser man tilbage på denne lange række navne på møllere i Brøns, først fæstere, så arvefæstere og endelig selvejere, er Peder Thomsen det store navn fra den gamle tid, men i nyere tid er det slægten Jacobsen, som helt behersker billedet, dygtige møllere, landmænd og forstmænd, flittige og sparsommelige, med udpræget sans for penges værdi, men også med sans for noget højere, både det nationale og det kristelige.

Anders Malling.

Bilag 1.

"Fundats for Peder Thomsens legat.

Givet til Guds Fre og til de Fattige og Nødtorftige deres Underholdning:

1. Til Orgelverkets Vedligeholdelse udi Brøns Kirke aarlig fire Rigsdaler, siger 4 Rdlr.

2. Til Organistens og Skolemesterens Underholdning her i Sognet, aarlig fire Rigsdaler, siger 4 Rdlr.

3. Til Huus-Arme og fattige Folk her i Brøns-Sogn, aarlig 13 Rigsdaler 1 Mark, siger 13 Rdlr. 1 Mk. Lybsk.

De fire Rigsdaler, som jeg haver given til Orgelverkets Vedligeholdelse, tages af Niels Nielsens udi Syndernes aarlige Landgilde, som han og Stafnens Besidder efter hannem aarlig i rette Tid skal betale, og, paa det at de des villigere og rigtigere skal betale, skal de ikke give nogen Lagie eller Aabodspenge (som ellers pleyer at gives paa Landgilde), men alene betale med gangbar Myndt.

De fire Rigsdaler, som jeg haver given til Organistens og Skolemesterens Underholdning, tages iligemaade af Niels Nielsens aarlige Landgilde, som ogsaa iligemaade, som de andre 4 Rdlr., uden Aabod eller I agie, skal betales allene med gangbar Myndt.

Til de 13 Rdlr. $1 \mathrm{Mk}$. Lybsk, som jeg haver given aarlig til Hus-arme og fattige her i Sognet, har jeg given en Obligation paa Capital 1000 Mark Lybsk, siger tusind Mark Lybsk, udgiven af Borgemester og Raad i Tønder 1709 paa S. Johannis Baptistæ Dag, til Hans Andersen Sognefoged, boendes i Hjemsted, paa hans Myndlings Mette Jessdatters Vegne, som til mig imod Capitalens Erliggelse er overdragen, som med Borgemester Lorentz Tychsens Paaskrift er samtykt og confirmeret d. 8. Nov. Anno 1713.

Kirkens Patroner vilde dette udi Kirkebogen uforandret lade indskrive, paa det at disse bemeldte 21 Rdlr. 1 Mk. dennem, som det er given, ikke skulde forvendes eller afgaa, men stedsevarende og evindeligen dennem aarligen erlegges og betales. 
Præsten og Kirke-Værger, som nu ere eller herefter kommendes vorder disse fornævnte $21 \mathrm{Rdlr}$. $1 \mathrm{Mk}$. aarligen ville oppebære og derfor qvittere og til dennem, som meldt er, rigtig uddele.

Om saa skede, at den fattige Capital, som staar ved Tonderby, blev opsagt, eller ikke raadeligt længer at lade staa, Kirkens Patroner, Præsten med flere gode Kristnes Raad vilde have Omsorg for, hvor Capitalen bedst kan blive anvendt og hensat, at de fattige og det, som er given til Guds Ere, intet skulle forkortes. Derfor vil Gud igjen være deres Løn.

Dette er saaledes min fuldkommen Vilje, hvorfor jeg det med egen Haand skriver og underskriver, og mit sædvanlig Zignet fortrykt.

Datum Brons Moll, Anno 1725 d. 25. May.

Peder Thomsen ${ }^{13}$

\section{Bilag 2.}

\section{Taxations-Instrument.}

Actum Brons Molle d. 5. Nov. 1755.

Som vi underskrevne 2 Tømmer og Muur Mænd at Requisitionem er bleven beordret at ilægge og taxere Brøns Mølles Bygninger, saavel som Mølle Werket, med sine Tilbehøringer, hvilcke worder eiet af Herr Birckvoigt Andersen, saaledes som det kunde staae, for alle videre Vurderinger og vi det, naar forlanges med Eed kunde stattææste. Saa haver vi oss i Dag udi samme Molle betideligen indfunden og i Herr Cantzellie Raad og Herretz foged Hoffmanns Overværelse, denne Mølle og sine Bygninger, cum pertinentiis nøye igiennemseet, og paa efterfølgende Maade, samme det retteste og beste, vi haver videt, taxeret.

Imo dend liden Molle

synden Broen og Slusen drives af overfaldende Vand, bestaar af 3 fag Huus, 20 foed breed a fag 14 Rd. . Quern Ladet med Vand og Knag Hiul samt anden Tilbehør ...................... 30 ,

Dend øverste Mølle-Steen 5 Tom tyck a 7 Rdl. .... 35 ,

Dend nederste Mølle-Steen 2 Tom tyck a 7 Rdl. .. 14 》

\section{IIdo Broen.}

Broen er 20 Allen lang og 12 Allen breed taxeret til 266 , 32 Sk.

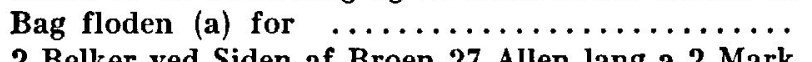

2 Belker ved Siden af Broen 27 Allen lang a 2 Mark Allnen $\ldots \ldots \ldots \ldots \ldots \ldots \ldots \ldots \ldots \ldots \ldots \ldots \ldots, 18$,

13 Stenger $\ldots \ldots \ldots \ldots \ldots \ldots \ldots \ldots \ldots \ldots \ldots \ldots \ldots \ldots, 4,4,16$,

7 Skotter $\ldots \ldots \ldots \ldots \ldots \ldots \ldots \ldots \ldots \ldots \ldots \ldots \ldots \ldots, 9,9$.

3 Maal Skøtter med Tilbehør ............ 5 ,

flanck Wercket paa Broen .............. 20,

48 Pæel under Broen og Bagfloden .......... 96 , 


\section{IIItio dend store Molle bestaar af}

7 fag 24 foed breed a $24 \mathrm{Rdl} . \ldots \ldots \ldots \ldots \ldots \ldots .168$ Rd.

2 Quern Lade, 2 Knag Hiule og 2 Vand Hiule ... 200 ,

3 lang Jern med Tapper, Riner og Wodderer (b) .. 60 .

Oven Steenen paa Rug Quernen, 5 foed $2^{1 / 2}$ Told (c) bred og 16/2 Told tyck, a Told $8^{1 / 2}$ Rdl. ...... 140 ,

Under Steenen paa samme Quern 11 Told tyck

a $\mathbf{8}^{1 / 2}$ Rdl.

\12 Sk.

93 24,

$80 \gg 36 \gg$

og 91/2 Told tyck a $8^{1 / 2}$ Rdl. .............

Under Steenen paa samme Quern 3 Told tyck a $8^{1 / 2}$

Rdl.

2 fag Quist Huus vesten ud ved Møllen med et

Kammer, Kielder og Skorsten udi a 20 Rdl. ...

$25>24$,

40

\section{Sals og andere Huus.}

14 fag Sals Huus, med 3 Skorstene udi nye Bygning af Grund Muur tæcket med Is Tag, eller Røer, 2 Arkover (d) og Caamerer paa Loftet, maalet overalt i Værelserne 32 foed breed a $50 \mathrm{Rdl}$......... de 2 Arkover og muret Kielder .............

5 fag Brøgger Huus norden ud fraa Vann Huuset med Oven, og Skorsteen udi, 20 fod breed a fag

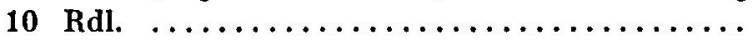

5 fag Loe og Baas 20 foed breed a 4 Rdl. .....

8 fag Vester Lade 19 foed breed a fag 20 Mark ..

13 fag Nor Lade 22 foed breed a fag 5 Rdl. .....

3 fag Vaand Huus 19 foed breed a fag $3 \mathrm{Rd}$. $24 \mathrm{Sk}$.

700 ,

160 ,

3 fag nye opbygte Smiede Huus, trecket med Pander a 12 Rdl. 24 Sk Summa ... 2508 Rd. 32 Sk.

Denne Taxation haver vi underskrevne Mrend fuldbyrdet efter beeste Skiønsomhed, Videnskab og forstand, uden ald Partiilighed og kand samme alle tiider, naar det vorder paadsked, med vorris Eed Bekræfte.

Som skedde Brøns-Molle ut supra.

Christen Pedersen af Bevtoft.

Jørgen Thomsen af wester Gasse.

Saaledes passeret udi min Overværelse attesteres.

G. Hoffmann"0.

(a) Et flaad, i reglen af brædder, i forlængelse af frislusen; forhindrer udhuling. (b) Rine, en bøjle, som den øverste mollesten er ophængt i. Wodderer ukendt. (c) Tommer. (d) Alkover. 


\section{Bilag 3.}

गInstrumenter og Redskaber, som horer til Mollernes Brug^.

A. I Vandmøllen.

3de Toeskjeps Ballier.

6 smaae do.

2 Grynkasser.

En Roldkasse. (a)

en Tonde.

3de Kornsolde.

en Kornbing. (b)

en ditto.

en gl. Rugsteen med jern Ring.

en halv Tonde til Kornopmaaling.

en Skjeppe.

en halv do.

2de Kaaber Toldkopper. (c)

en lang Bikker. (d)

en Takkel med 3de Stryger. (e)

en stor jern Knibtang.

en stor jern Mokker. (f)

3de Kiiljern. (g)

en Dombart. (h)

en stor Buesave.

en Slibesteen med Trug og Vinde.

14 Stkr. jern Bikkerer.

2 spids do.

en liden Ballie.

et Kornsold.

en jern Stang.

en Koefod.

og B. I Veirmøllen:

En Toeskjeps Ballie.

3de smaae Ballier.

en Hammer.

et Kiiljern.

en Dombart.

en Sauge.

og et Kaaber Toldkop.

(a) Formentlig en kasse på ruller eller hjul.

(b) Kasse, kiste.

(c) Mål af kobber, 1/20 skæppe, hvormed man opmålte toldkornet. Deto toldkopper findes nu hos fru Thoma Jacobsen i Aabenraa.

(d) Bildejern, hammer med mejselformet hoved til at skærpe møllesten.

(e) Talje med 3 skiver.

(f) stor hammer, forhammer, med fladt hoved. 
(g) Kiler til fastgoring af mollesten.

(h) ukendt redskab. Ordet stăr måske i forbindelse med det tyske skældsord »Dumm' Bart «; jvf. »jomfru « i brolæggersproget. ${ }^{37}$

Bilag 4.

H. C. Jacobsens vurdering af hoveriet til Brons molle 1853.

Taxatorerne angiver allerforst en Beregning paa 24 Sk. pr. Plov aarlig til at dxkke det saakaldte Spand og Gang Arbeide ved Mollens og Broens Reparationer, som udgjør 60 Rd. Naar de dermed meener de sædvanlige eller almindelige Præstationer af Egter, saa kan det omtrent passe, f. Eks.

Rd. Sk.

a. hvert 16. Aar behøves i Almindelighed 2 Vandhiule bestaaende af 96 Lbfod Ege Træ eller 6 Las a 5 Rdl., er 30 Rdl., altsaa aarlig ...........

b. Hvert 30. Aar behøves i Almindelighed 2 Axeler, disse at hente paa Østkøsten af 8 Miiles Afstand med $6-8$ Heste hver og 4 Karle. Saadan en Reise medtager 3-4 Dage. Vil man leie dertil, koster det sædvanlig 30 Rdl., undertiden meere for hver; Er for dem begge $60 \mathrm{Rd}$, altsaa aarlig .........

c. En nye Steen hvert 8 . Aar til hver af de 3 Qverne er i Fragt for alle 3 Qverne a Styk 3 Rd. 16 Sk., 10 Rd. eller aarlig $\ldots \ldots \ldots \ldots \ldots \ldots \ldots \ldots$

d. 12 Tyldt Breder og 1 Td. Tiære aarlig, til Vandhiul Skovle, Beklædning paa Mollen, Maalerender og Flod a Tyldt 2 Mk. 12 Sk. i Fragt .........

e. Desforuden forbruges omtrent aarlig 10 Læs Egetræ for det Meste til Reparationer og Gangtøi a 4

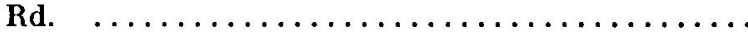

1. Paa denne Maade udkommer Taxatorernes førstanførte Sum saa omtrent $\ldots \ldots \ldots \ldots \ldots \ldots \ldots$

2. De anfører dernæst en Dæmning, som man maa have sammenkiørt uden for Broen, naar Broen ombygges af Nyt eller den er bleven utæt ved Ridstæget eller Grundværket. Dertil behøves omtrent 12.000 Læs Jord. Naar Reparationen er færdig skal dette bort igien, men sædvanlig faar man kuns de 3/4 Deele, altsaa 900 Las eller i Alt 2100 Læs. For at lade og paakiøre dette samt Haandarbeidet ved Digets Sætning regnes $6 \mathrm{Sk}$. pr. Læs, er 262 Rd. 12 Sk. Dette regner man skeer $i$ det Mindste hvert 15. Aar, omtrent siden 1827 er det skeet 2 Gange og er altsaa aarlig dertil ....... 
3. Derefter anfurer de Planeringen ved Bagdybet, men dertil horer ogsaa Jordkiørselen til Brohovederne og et falles Veilykke og Damning, hvortil sædvanligvis behoves 20 Vogne a 1 Rd. og $30 \mathrm{Kar}-$

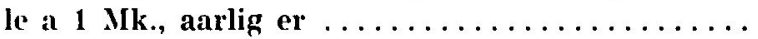

4. Fremdeles anforer de Molledammens Rensning til 250 Rd. hvert 60. Aar. Denne regning er ligesom de forrige uantagelig. Skaulund Molledam, som vist ikke er over 1 Tonde Land stor, har kostet 5000 Rd. at rydde. Sat nu, at det ene Tusinde Rigsdaler gik til 1 Process, saa var det dog 4000 Rd. Omendskiınt der siden denne Tiid flere Gange er bleven noget opryddet, trænger den igien til en fuldkommen Rensning, Ostergaards Molledam (r) omtrent 1 Tonde Land stor, denne kostede 4000 Rd. at rydde uden Process. Brons Molledam er vistnok $40 \mathrm{~T}$. Land $\mathrm{i}$ storrelse. Skulde man nu derefter giore Beregninger og man endogsaa kuns regnede, at den behovede at ryddes Engang hvert IIundrede Aar, saa blev det dog ararlig 1600 Rd., men jeg satter det kuns til ........... 200

5. Transporten med Toldkornet til Tonder eller Hoyer anforer de til 33 Rd. Hyordan de vil faa de ifolge deres egen Taxt anforte 500 Td. Rug og Malt, 15 Td. Hvede og 50 Td. Brendkorn, ialt 565 Td. transporteret fire Miil for neppe $3 \mathrm{Sk}$. pr. Td., forstaar jeg ikke. Efter hvad det altid har kostet, saa er der bleven betalt for 1 Tonde Hvede eller Rug 16 Sk. Altsaa 375 Td. Rug, 15 Td. Hvede, ialt 390 Td. a $16 \mathrm{Sk}$, og 125 Td. Malt, 50 Td. Brendkorn a 12 Sk. .............. 173

6. Mollens Tækning har de anfort for Tag og Reeb med 80 Rd., men de har glemt Haandlanger Arbeidet og Ryggen at grave, kiore til og ligge paa, som jeg anslaar til $16 \mathrm{Rd}$. lot er beregnet at ligge i 16 Aar, omendskiondt den sidste Trkning laa

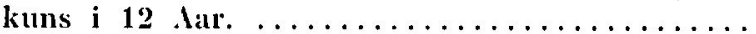

7. Mulledæmningens Vedligeholdelse har Taxatorerne kuns anslaaet til 6 Rd. For 121 Vaand eller 2 2/5 Sk. pr. Vaand. Jeg har i cn Række af Aar holdt $1 \frac{1}{2}$ Vand for Vester Vedsted Sogn for 1 Rd. aarlig, og 1 Vaand for Seem Sogn, som har betalt mig, hvad der behøvedes, og som sædvanlig har 
kostet 40 Sk. aarlig. Jeg har anslaaet hele Dæmningen til 24 Sk. pr. Vaand, som er vist meget billigt, men bliver $\operatorname{dog}$ aarlig $\ldots \ldots \ldots \ldots \ldots \ldots \ldots$

8. Videre ere Taxatorerne ikke komne; de har ikke giort Regning paa, at Broen og Sluseværket i det Mindste hvert 30 Aar skal opbygges af $\mathrm{Nyt}$; ja den sidste Broe stod kuns i 22 Aar. Jeg har beregnet det saaledes: I Broen med Tilbehør er der efter Opmaaling 218 Lbfod fyr og $3660 \mathrm{Lbfod}$ Ege Træe, og i Huuset over Hiulene op i Tagladet 68 Lbfod fyr og 941 Lbfod ege Træe, ialt $286 \mathrm{Lbfod}$ fyr og $4601 \mathrm{Lbfod} \mathrm{Eg.} \mathrm{Fyr} \mathrm{Traet} \mathrm{beregnet} \mathrm{til} 20$ Lbfod pr. Læs er 14 Læs a 4 Rd. Egetræet 16 Lbfod pr. Læs er 287 Læs a 5 lid. Egetræet er beregnet $1 \mathrm{Rd}$. dyrere pr. Læs, deels fordi det skal hentes i Skovene, deels ogsaa fordi det som raa Material har mere Overmaal. Rigtig nok ere Læssene ikke store, men altid større ansatte som Hørlæssene, og fragten er $i$ forhold dertil; thi hvem kan kiore herfra til Haderslev, Apenrade eller de paa Østkøsten liggende Skove, ikke at tale om at reise til Flensborg for $4-5$ Rigsdaler. 34 Tyld Breder a 2 Mk. 12 Sk. i fragt 31 Rd. 8 Sk. Kiorselen hiemme med Leer, Jord etc. anslaaes vist ikke for høit, naar man regner det paa 150 dage med 1 Vogn a 1 Rd., 150 Rd. Haandarbeidet 12 Karle i 13 Uger til begge Deele at slaa Pæle, bære Tømmer og Jordarbeidet a $16 \mathrm{Sk}$. for hver Karl: 312 Rd. Ialt 1984 Rd. 8 Sk. Dette fordeelt paa 30 Aar bliver aarlig $\ldots \ldots \ldots \ldots \ldots \ldots \ldots \ldots \ldots$

9. Mollehuset og det derværende Værk er vel ikke udsat for at forraadne, i det Mindste en Deel deraf, men dog i Tidens Længde kan det som alt andet ogsaa trænge til at opfores af Nyt, og om ikke for, saa er det Ildebranden underkastet, og man overdriver vist ikke, om man giør Regning paa, at det skal opføres af Nyt 1 Gang hvert 100 Aar. Min Beregning er som folger: I Mollebygningen er ligeledes efter Opmaaling $1124 \mathrm{Lbf}$ fyr Trae og 1306 Lbf. Egetræe, og i Molleværket 193 og 878 , ialt 1317 Lbfod fyr Træe og $2184 \mathrm{Lbfod} \mathrm{Eg.}$ Fyrtræet beregnet som før efter 2 Lbfod pr. Læs er 66 Læs a 4 Rdl.: 264 Rdl. Egetræet 16 Lbf. pr. Læs er 136 Læs a 5 Rd.: 680 Rd. 211/2 Tyldt Breder a 2 Mk. 12 Sk. i fragt er 19 Rd. 34 Sk. 100 
Td. Kalk a 7 Sk. i fragt er 14 Rd. 28 Sk. 3000 Muursteen $200 \mathrm{pr}$. Læs er $150 \mathrm{Læs}$, disse at hente i Vinom eller Spannedgaard paa $1^{1 / 2}$ Miils Afstand pr. Læs 1 Rd. er 150 Rd. 3 Læs Jerntøi at hente i Flensborg a Læs 8 Rd. er 24 Rd. 735 Tag Pander til Vandhiulenes Skierm i Apenrade 4 Isas a 4 Rd. er 16 Rd. Desforuden behoves Egter hiemme til Leer, kløvede Steen og Marksteen til Grundvold og Muur ved Vandsiden, samt Sand og Jord, som lav ansat vist nok kan beregnes paa 300 Dage med 1 Vogn a 1 Rd.: 300 Rd. Og Haandarbeidet beregnet til 12 Karle daglig i 15 Uger bliver 1070 Dage a $16 \mathrm{Sk}$. om Dagen paa egen Kost: $356 \mathrm{Rd}$. 32 Sk. Ialt 1824 Rd. $46 \mathrm{Sk}$., dette fordeelt efter ovenanfort paa 100 Aar bliver aarlig .........

Rigsdaler ...637

$31 \mathrm{Sk}^{34}$

\section{KILDER OG HENVISNINGER}

Foranstảende artikel om Brons mølle er et sammendrag af et næsten fire gange så stort manuskript, hvoraf et duplikat er deponeret i Landsarkivet i Åbenrá. Der henvises dertil under navn af "manuskriptet «.

Hovedgrundlaget for dette manuskript er "Brons Molles Arkiv« (B.M.A.), en stor samling af dokumenter, originaler så vel som kopier, der er samlet af Lydik og Aage Jacobsen. Dette arkiv, som der ofte henvises til, er nu deponeret i Landsarkivet i Åbenrå.

1. Kong Valdemar den Andens Jordebog, udg. og oplyst af $O$. Nielsen, Kobenhavn 1873.

2. Rigsarkivet: Tyske Kancellis indenlandske afdeling. Akter angående Delingen af Arven efter Hans den Eldre 1580-84 (100). Jeg har med tak modtaget denne oplysning af arkivar Emilie Andersen.

3. Samlinger til Jydsk Historie og Topografi, Bd. III, S. 180.

4. Disse og de fleste af de folgende oplysninger fra tidsrummet $\mathbf{1 6 0 0}$ -35 stammer fra undersogelser i Rigsarkivet, foretaget af postmester Olav Kjems, Kobenhavn, der har meddelt sine resultater til moller Aage Jacobsen og elskværdigt givet mig tilladelse til at benytte dem her.

5. Rigsarkivet. Haderslevhus' Regnskab for $1635-36$, bilag nr. 303-4. Kopier i B. M. A.

6. Haderslevhus' Regnskab for 1636-37, bilag nr. 271-4. Kopi i B. M. A.

7. Rigsarkivet. Rtk. Kontorer for Slesvig. Akter vedr. Moller og Fiskerier i Haderslev Amt. Ca. 1681-97. Kopi i B. M. A.

8. Olav Kjems som anført.

9. Rigsark. Haderslev Amts Regnskab 1662-63. Bilag nr. 7. Kopi i B. M. A. 
10. Samme for $1688-89$. Kopi i B. M. A.

11. Samme for $1687-88$, bilag nr. 4 . B. M. A.

12. Et inventarium, som blev opskrevet ved denne lejlighed, er gengivel i manuskriptet.

13. Kirkens patroner har ganske rigtigt ladet dette indskrive pii forste blad $i$ en ny regnskabsbog for legatet; den opbevares nu på Landsarkivet i Ảbenrå. Retskrivningen er her noget moderniseret, jvf. Hans de Hofmans Fundationer. Tom. IV, Kiob. 1759, pag. 576.

14. Rigsark., Rentekammerets tyske Forestillinger. Kopi i B. M. A.

15. Originalen i B. M. A.

16. Vestkysten «s kronik 8. febr. 1945.

17. H. A. Brorson: Troens rare Klenodie, nr. 271.

18. Rigsark., Haderslev Amtsregnsk. 1687-88, bilag 4. B. M. A.

19. Originalen i B. M. A.

20. Landsark. i Ábenrå, Haderslev Amts Arkiv, Sager fra Slesvigske Registr. 195 A.

21. Rigsark., Rentekam. tyske Forest. Kopi i B. M. A.

22. Hviding Herreds Skyld- og Panteprotokol, 28. marts 1749.

23. Hans Kyrre: Gamle jydske Vandmøller. Saml. til Jydsk Historie og Topografi, 4. Række, II. Bd., s. 252-69.

24. Originalen i B. M. A.

25. Kopi i B. M. A.

26. Steen B. Bocher: Vandkraftens Udnyttelse i det sydlige Norrejylland for og nu. Kobenhavn 1942, s. 176.

27. Dels kopier, dels originaler i B. M. A.

28. Koncept i B. M. A.

29. Som 27.

30. Register til Stamtavle over SIægten Jacobsen. Ved Hans Christian Jacobsen 1872. Viderefort af Aage Jacobsen til 1945. Privat tryk, Ribe 1946.

31. Meget udforligere omtalt i manuskriptet.

32. Orig. i B. M. A.

33. N. C. Simonsen: Molleeiernes Stilling for og efter Lov af 14 de April 1852. Skive 1871.

34. Koncept i B. M. A.

35. Udforligt refereret $i$ manuskriptet.

36. Bøcher, anførte værk s. 239.

37. Adjudications-Contract i B. M. A. 